\title{
Article \\ Mineralogy of Miocene Petrified Wood from Central Washington State, USA
}

\author{
George E. Mustoe ${ }^{1, *(\mathbb{D} \text { and Thomas A. Dillhoff }}{ }^{2}$ \\ 1 Geology Department, Western Washington University, Bellingham, WA 98225, USA \\ 2 Evolving Earth Foundation, P.O. Box 2090, Issaquah, WA 98207, USA; tdillhoff@evolvingearth.org \\ * Correspondence: mustoeg@wwu.edu
}

check for

updates

Citation: Mustoe, G.E.; Dillhoff, T.A. Mineralogy of Miocene Petrified Wood from Central Washington State, USA. Minerals 2022, 12, 131. https:// doi.org/10.3390/min12020131

Academic Editor: Gernot Nehrke

Received: 17 December 2021

Accepted: 19 January 2022

Published: 23 January 2022

Publisher's Note: MDPI stays neutral with regard to jurisdictional claims in published maps and institutional affiliations.

Copyright: (C) 2022 by the authors. Licensee MDPI, Basel, Switzerland. This article is an open access article distributed under the terms and conditions of the Creative Commons Attribution (CC BY) license (https:// creativecommons.org/licenses/by/ $4.0 /)$.

\begin{abstract}
Silicified wood occurs abundantly in Middle Miocene flows and sedimentary interbeds of the Columbia River Basalt Group (CRBG) in central Washington State, USA. These fossil localities are well-dated based on radiometric ages determined for the host lava. Paleoenvironments include wood transported by lahars (Ginkgo Petrified Forest State Park), fluvial and palludal environments (Saddle Mountain and Yakima Canyon fossil localities), and standing forests engulfed by advancing lava (Yakima Ridge fossil forest). At all of these localities, the mineralogy of fossil wood is diverse, with silica minerals that include opal-A, opal-CT, chalcedony, and macrocrystalline quartz. Some specimens are composed of only a single form of silica; more commonly, specimens contain multiple phases. Opal-A and Opal-CT often coexist. Some woods are mineralized only with chalcedony; however, chalcedony and macrocrystalline quartz are common as minor constituents in opal wood. In these specimens, crystalline silica filling fractures, rot pockets, and cell lumen may occur. These occurrences are evidence that silicification occurred as a sequential process, where changes in the geochemical environment or anatomical structures affected the precipitation of silica. Fossilization typically began with precipitation of amorphous silica within cell walls, leaving cell lumen and conductive vessels open. Diagenetic transformation of opal-A to opal-CT in fossil wood has long been a widely accepted hypothesis; however, in opaline CRBG specimens, the two silica polymorphs usually appear to have formed independently, e.g., woods in which cell walls are mineralized with opal-A but in which lumen contain opal-CT. Similarly, opal-CT has been inferred to sometimes transform to chalcedony; however, in CRBG, these mixed assemblages commonly resulted from multiple mineralization episodes.
\end{abstract}

Keywords: petrified wood; opal-A; opal-CT; chalcedony; Columbia River Basalt Group

\section{Introduction}

Silicified wood has worldwide distributions. These tree remains have received considerable attention from paleontologists who strive to understand the evolution of plant communities, interpret paleoenvironments, and evaluate ancient climates. The mineralogical processes that result in wood petrifaction have long been studied by petrologists and geochemists [1-19]; however, knowledge remains imperfect. In particular, the hypothesis of silica permineralization, where intact cellular tissue is entombed within a silica matrix, has been widely accepted despite a lack of supporting evidence [20].

One of the challenges for interpreting the fossilization process is that silicification of wood may proceed by multiple pathways; evidence from one locality may not be applicable to fossil woods from other deposits. A second complication comes from the difficulty in making accurate mineral identifications based on limited analytical evidence. This study involves the study of a diverse data set using a broad combination of methods. The results show that the silicification of wood may be surprisingly complex. Silicified woods from a single CRBG locality may contain silica in both crystalline and noncrystalline forms, 
these variations sometimes occurring within a single small specimen, or even within adjacent cells.

The preservation of silicified tissue of woods engulfed by lava flows of the CRBG is unusual because high magma temperatures commonly cause combustion of organic matter, producing hollow molds. This process is well documented from modern observations of basaltic flows of the Hawaiian Kilahuea volcano entering forested areas, and from tree molds and lava casts that resulted from past eruptions. Lava tree moulds are found at many volcanic areas in western USA [21]. As discussed later in this report, the preservation of silicified tissue at CRBG sites is a result of water saturation of the wood from a variety of causes. This moisture provided a high degree of thermal protection.

\section{Geologic Setting}

Fossil wood has been found at many locations within the middle Miocene Columbia River Basalt Group (CRBG). This report focuses on four locations in central Washington that span a Middle Miocene age range of $\sim 1.1 \mathrm{Ma}$ (Figures 1 and 2). These sites were selected because their stratigraphic positions are known with reasonable certainty (Figure 3). Equally important, the taphonomy of the silicified logs provides an indication of the paleoenvironments for each of the four fossil wood localities. A principal goal of our investigation was to study the mineralogy for woods that were preserved under differing environmental conditions and geologic settings. These fossil woods were considered to possibly provide an excellent opportunity for documenting possible mineral changes that occurred during diagenesis. Finally, the research demonstrates the need for using multiple analytical methods to study the mineralogy of silicified wood.

Middle Miocene forests in central Washington State existed at a time when basaltic lava episodically inundated large areas of the inland Pacific Northwest. These outpourings were related to the migration of a mantle plume along a northwestern path that sequentially produced volcanic activity that began in northern Nevada and later extended across southeastern Oregon and Washington and western Idaho to reach its present location beneath Yellowstone National Park in Wyoming [22-25]. Stacked lava flows of the Columbia River Basalt Group (CRBG) cover $210,000 \mathrm{~km}^{2}$ [6]. In total, $80 \%$ of this volcanic activity occurred between 16.5 to $15.6 \mathrm{Ma}$, with the youngest flows dated at $6 \mathrm{Ma}$ [26-28].

Sagebrush/bunchgrass steppe flora is presently characteristic of arid central Washington and Oregon; the Miocene paleoclimate was slightly cooler and more humid than today, with significant summer rainfall [29]. Quiescent episodes between eruptive cycles allowed the widespread establishment of temperate forests and local swamp habitats. Subsequent eruptions buried tree remains from both environments; silica released from devitrification of volcanic glass resulted in mineralization of ancient plant tissue that locally ranged from seeds and small limbs to large logs. 


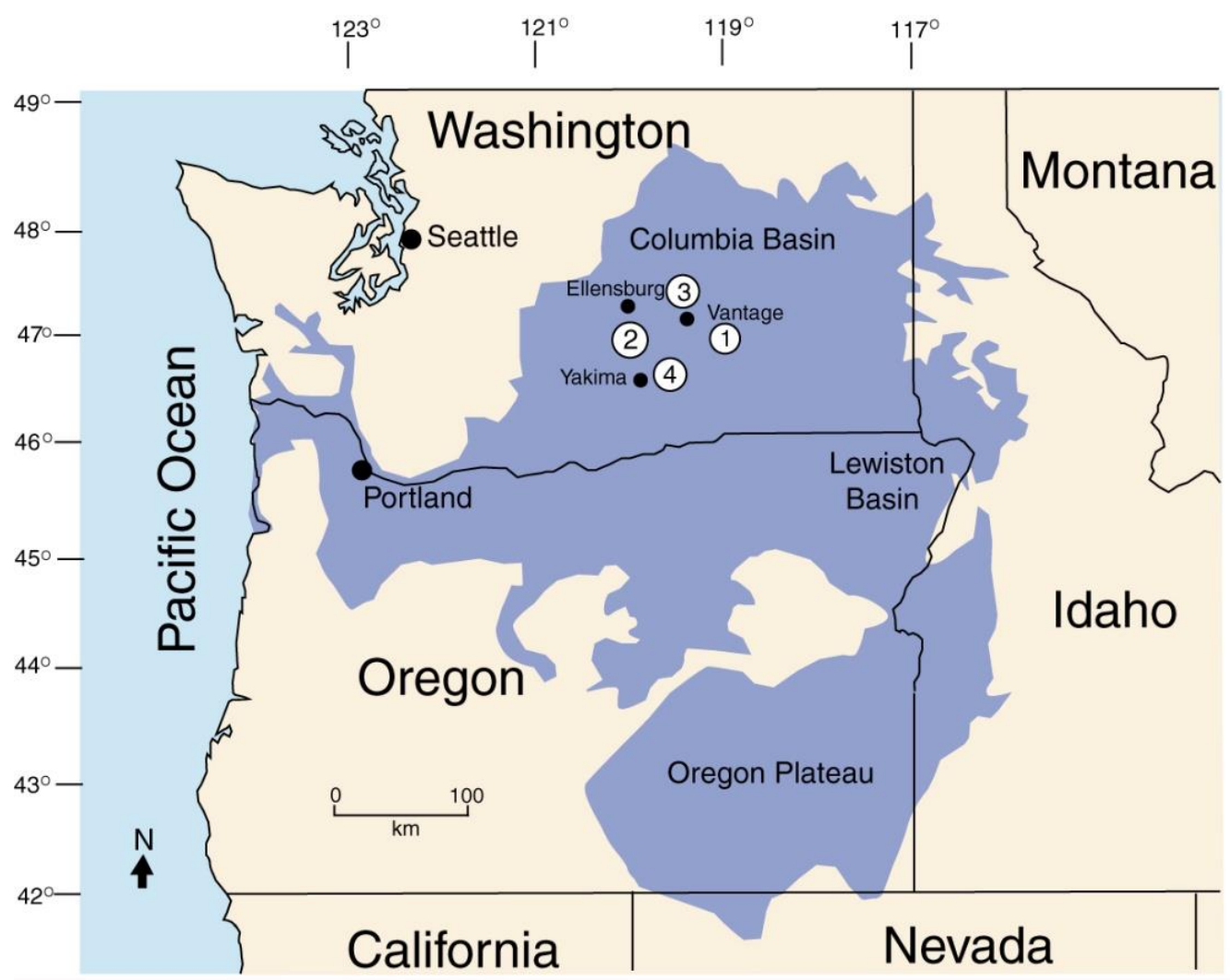

Figure 1. Fossil wood localities studied in this report. (1) Saddle Mountain. (2) Umtanum Canyon; (3) Gingko Petrified Forest State Park; (4) Yakima Ridge Fossil Forest. Base map modified from [26].

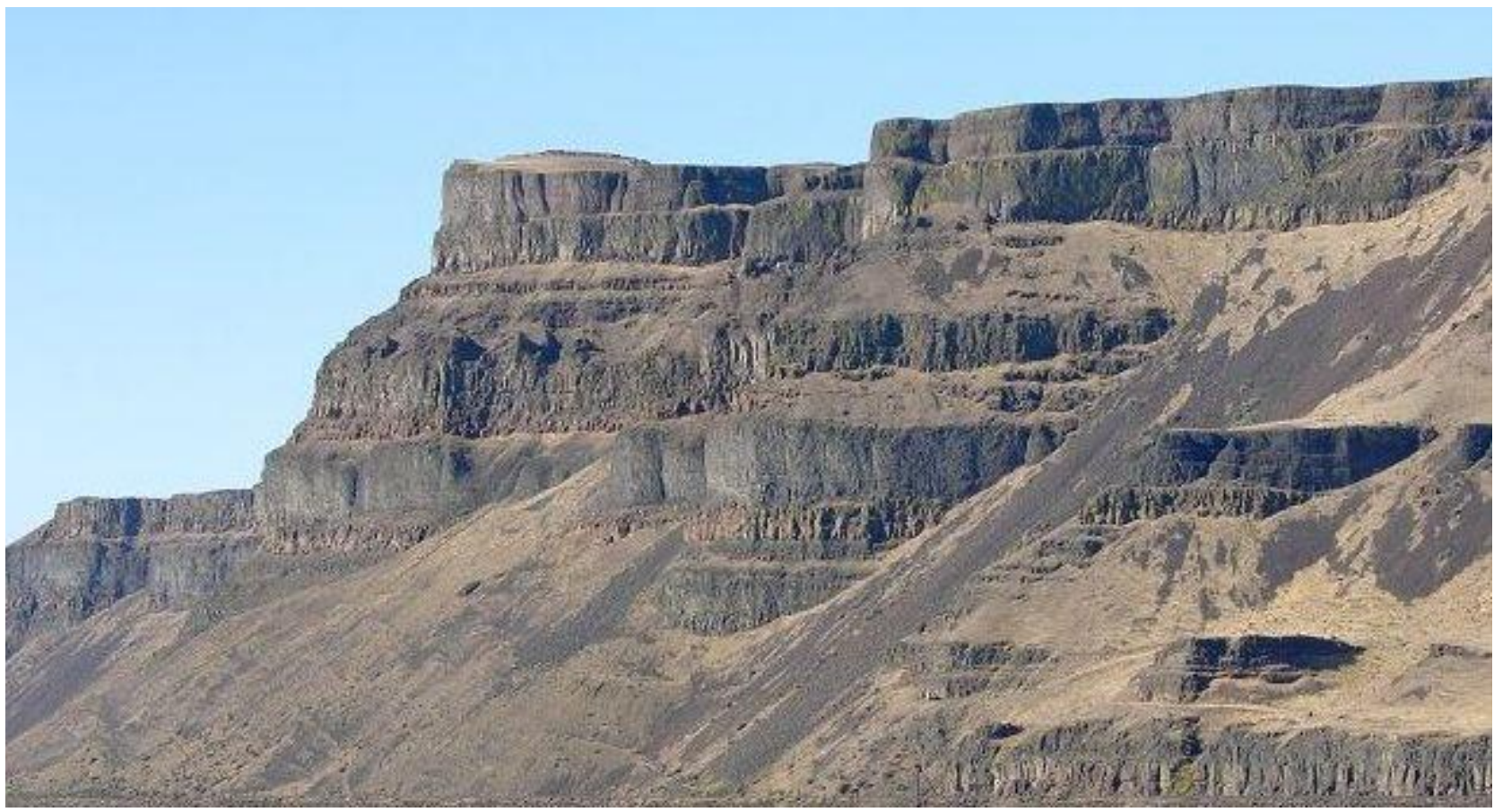

Figure 2. Columbia River Basalt Group flow on west side of Columbia River, Douglas County, WA, USA. 


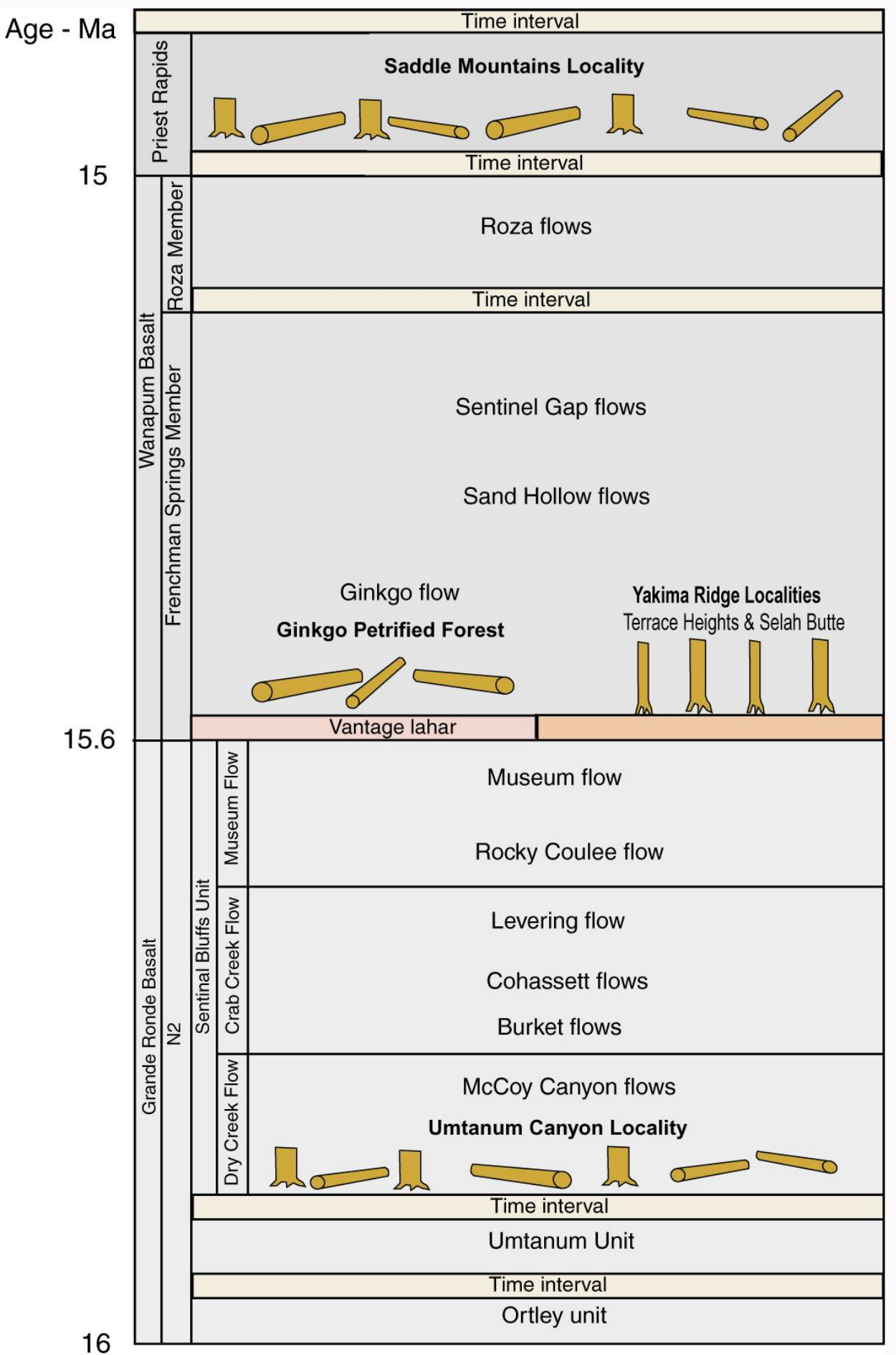

Figure 3. Stratigraphic positions of fossil localities studied in this report. Modified from [30].

The use of silicified wood for the manufacture of arrow heads is evidence that Native Americans were well-aware of fossil wood in central Washington [31]. By the late 1800's, Caucasian settlers likely observed the surficial abundance of petrified wood at some localities; an early scientific description appeared in 1893 [32]. Notable discoveries were made in 1927 by highway workers in the Vantage area. Now a Washington State Park, Ginkgo Petrified Forest is the best-known location; however, fossil wood occurs at many other locations in central Washington. Beck collectively referred to these localities as 
the Russell forests in commemoration of I.C. Russell's pioneering geological work [33]; however, this terminology is now seldom used. In 1975 the Washington State Legislature adopted petrified wood as the official state gem.

\section{Locations Used in This Study}

\subsection{Ginkgo Petrified Forest}

This location occurs in the arid hills west of the Columbia River (Figure 4A-C). In 1930, Central Washington College of Education (now Central Washington University) geology professor George F. Beck observed a man coming down from the hills near Vantage carrying a large piece of petrified wood [34,35]. Beck and his students soon began to explore the area. Their excavations yielded a multitude of specimens representing many species of ancient trees, including the first known example of fossil Ginkgo wood. Beck became the chief lobbyist for the preservation of the Vantage fossil forest, convincing the Washington Legislature to buy a key 4-hectare (10 acre) parcel in 1935. Ginkgo Petrified Forest State Park opened to the public in 1938. The present visitor center was built in 1953, and the park's land area was greatly expanded in 1975.
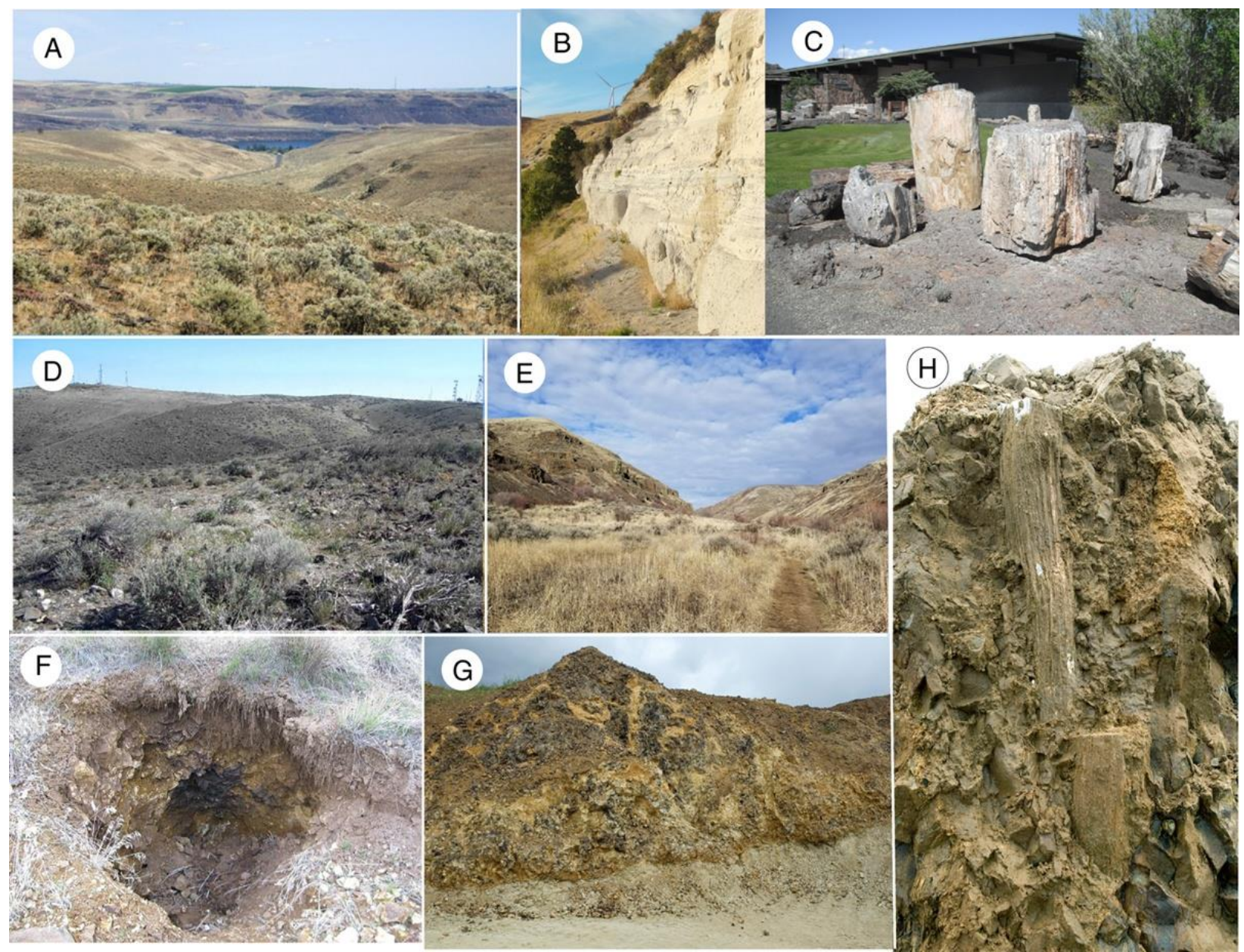

Figure 4. Locations of fossil wood localities studied for this report. (A) Ginkgo Petrified Forest State Park, looking east toward the Columbia River. (B) Contact between Vantage Formation lahar sediments and the overlying Museum Flow. (C) Fossil logs on display at Ginkgo Petrified Forest State Park visitor center. (D) Summit ridge of Saddle Mountain. (E) Yakima Canyon Umtanum Creek locality. (F) Excavation site on hillside bordering Umtanum Creek. (G) Yakima Ridge Terrace Heights locality showing contact between basalt flows and underlying lacustrine sediment. (H) Upright tree trunks preserved in basalt at Terrace Heights. 
Because the fossil logs were typically buried in horizontal positions, Beck [36] assumed that the petrified trees represented fluvially transported logs that had been transported into an ancient lake, which he named Lake Vantage. The waterlogged wood was protected from combustion when the lake basin was inundated by lava. This "rafted forest" hypothesis was linked to the observation that the fossil wood predominantly consists of unrooted logs that have been stripped of limbs and bark. The Lake Vantage interpretation was based on the preservation of silicified logs in pillow basalts immediately above a fine-grained sedimentary interbed known as the CRBG Vantage Member. The largest of these logs was reported to be 2.75 min diameter [36].

More recently, the Vantage Member sediments have been interpreted as a lahar deposit, where a regional volcanic eruption decimated hillslope forests to produce floating logs that were transported to a lake that formed when the ancestral Columbia River was blocked by lava flows. The floating logs subsequently became entombed within a lava flow $[37,38]$, where they were preserved as log rafts. Thousands of individual logs represent trees from a variety of habitats, the greatest taxonomic diversity of all known CRBG petrified wood localities. Taxa are a mix of hardwoods and softwood $[33,39]$.

Beck made the first attempts at analyzing the taxonomy of fossil wood from the Vantage area [33,34,36,40]; his research provided an important foundation for later studies [41-46].A recent reexamination of specimens from these earlier studies provided better understanding of the geologic setting, paleoenvironment, and taxonomy of fossil wood from deposits at Ginkgo Petrified Forest [47]. This work updated and expanded the earlier publications and included wood types that had not previously been described. Currently, the assemblage at Vantage is regarded as the single most diverse fossil wood locality from the Miocene of North America.

The silicified logs comprise at least six gymnosperms and 34 angiosperms. Beck's unpublished field notes recorded that $\sim 50 \%$ of the fossil logs represented upland conifers of the Piceoxylon type. Lowland conifers (e.g., Cupressinoxylon and Taxodioxylon) are abundant. Among the angiosperms, Ulmus (Elm) comprised 20\% of the logs. No other angiosperm exceeded 5\%; many taxa were present in only small amounts. The dominance of upland conifer and the diversity of angiosperms are consistent with the lahar theory $[37,38]$ where a mudflow may have caused tree remains from a variety of habitats to accumulate in a single deposit.

\subsection{Saddle Mountain Fossil Locality}

The Saddle Mountains extend as a $50 \mathrm{~km}$ long ridge, accessed by a network of unpaved roads that branch from Highway 24 a few $\mathrm{km}$ east of the village of Mattawa [48] (Figure 4D). Reidel [49] published a detailed geologic map of the Saddle Mountains. Topography is shown on a 1965 topographic map [50]. The area has long been popular with fossil wood collectors because much of the land area is publicly owned under the auspices of the Bureau of Land Management, and recreational collecting is allowed. Basalt flows are mostly obscured by alluvium; most fossil wood specimens have been discovered by hand-dug excavations. Stratigraphic relationships are therefore difficult to ascertain. Silicified wood occurs in an ash layer from a Cascade Range volcanic event, within a pillow lava/palagonite zone that lies at the base of the Priest Rapids basalt flow. No scientific studies have been done at this locality, which is one of the youngest known fossil wood occurrences in central Washington, with an approximate age of $15 \mathrm{Ma}$. Like Ginkgo Petrified Forest fossil wood at Saddle Mountain includes both gymnosperms and angiosperms; however, the diversity of the flora remains unknown. The combination of stumps, logs, limbs, and forest litter is very different from the taphonomic conditions present at Ginkgo Petrified Forest, which is evidence that the Saddle Mountain fossil wood was derived from a standing forest rather than represented transported material. 


\subsection{Umtanum Canyon Fossil Locality}

Fossil wood occurs at several locations on slopes bordering the Yakima River, south of Ellensburg, WA. The best-known locality is at Umtanum Canyon, reached by crossing the river on a pedestrian suspension bridge to reach a trail that follows the course of Umtanum Cree (Figure 4E,F). Like Saddle Mountain, the BLM land has a long history of public access. A road connecting between Ellensburg and Yakima was constructed in the late 1800's; a suspension bridge accessing Umtanum Canyon dates back more than a century to construction of the railway line on the west bank of the Yakima River. Public access to the area thus has a long history; however, there is no record of the first fossil wood discoveries. Recreational collecting dates at least to the 1950 's, reaching great popularity by the mid 1960's.

Fossil logs at both the Saddle Mountain and Umtanum Canyon localities are typically found in horizontal positions. At both sites, "bog wood" occurs where wood fragments have been cemented together by silica in a wetland environment (Figure 5). Silicified wood also occurs at locations in the Yakima Canyon area that are outside the topographic boundaries of the Umtanum Canyon locality. No studies have been made of these occurrences. In this report, specimens from these outliers are cataloged with a YC-prefix. These samples have diverse mineral compositions, but tend to have greater abundances of chalcedony (Appendix A), suggesting that they come from strata that are not directly correlative with the Umtanum Canyon strata.

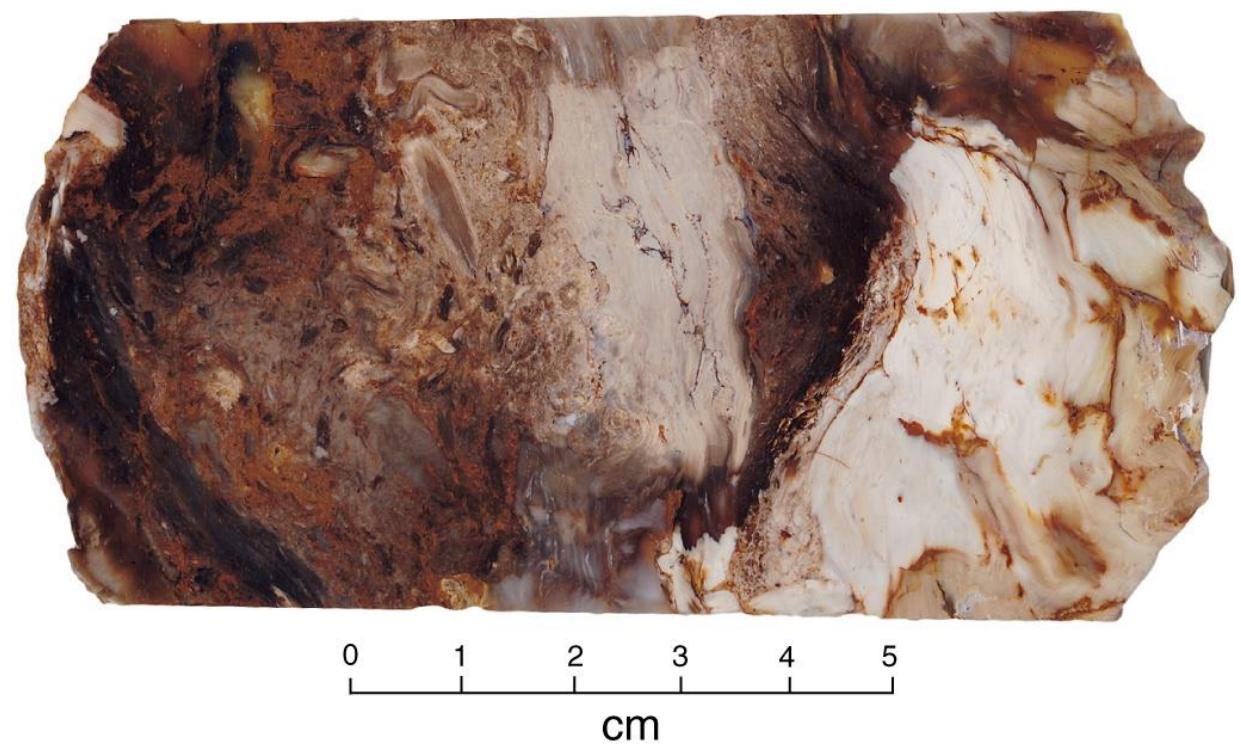

Figure 5. "Silicified bog" from Saddle Mountain fossil locality.

\subsection{Yakima Ridge Fossil Forest}

Two locations near the city of Yakima contain upright silicified trunks enclosed in a basalt flow that overlies argillaceous sediment.

The Terrace Heights location was discovered in 2007 when a landowner found fossil wood on his property on a hillside east of Yakima (Figure $4 \mathrm{G}, \mathrm{H}$ ). The other locality is a rock quarry on Selah Butte, northeast of Yakima.

At Terrace Heights, excavations with heavy equipment revealed at least 150 silicified trees that were preserved in upright position within a basalt flow underlain by a thick clay layer (Figure 4G). Trunk diameters range from $7.5 \mathrm{~cm}$ to over $45 \mathrm{~cm}$. Geochemical analysis of the basalt places the flow within the Frenchman Spring Member of the Wanapum Basalt Formations, with an approximate age of $15 \mathrm{Ma}$ [51]. The property owner, who was a heavy equipment operator by profession, rather quickly excavated all of the fossil trees, limiting opportunities for scientific study. Photos of the in-situ trees taken soon after the discovery were published in newspapers $[52,53]$. The only scientific examination was made after 
most of the trunks had been excavated $[51,54]$. The preliminary interpretation was that the locality represents a standing forest that colonized a dry lakebed. The trees were drowned when the lake refilled and were then preserved when the area was subsequently inundated by lava.The fossil trees represent hardwood forest, which is a contrast to other CRBG forest assemblages where conifers are a common element. The most common taxa are Carya and Ulmus (Elm), with minor amounts of Acer, Liquidambar, and Gleditsia.

Fossil wood at Selah Butte likewise represents hardwood forest. The taphonomy is less evident than at Terrace Heights, because Selah Butte specimens come from a quarry where the commercial goal is to produce rock for construction purposes, not extraction of intact fossils. The paleoflora is comprised of angiosperms that include Ulmus, Liquidambar, and Fraxinus. Selah Butte specimens commonly show charred exteriors that resulted fromstanding trees becoming engulfed in magma (Figure 6).

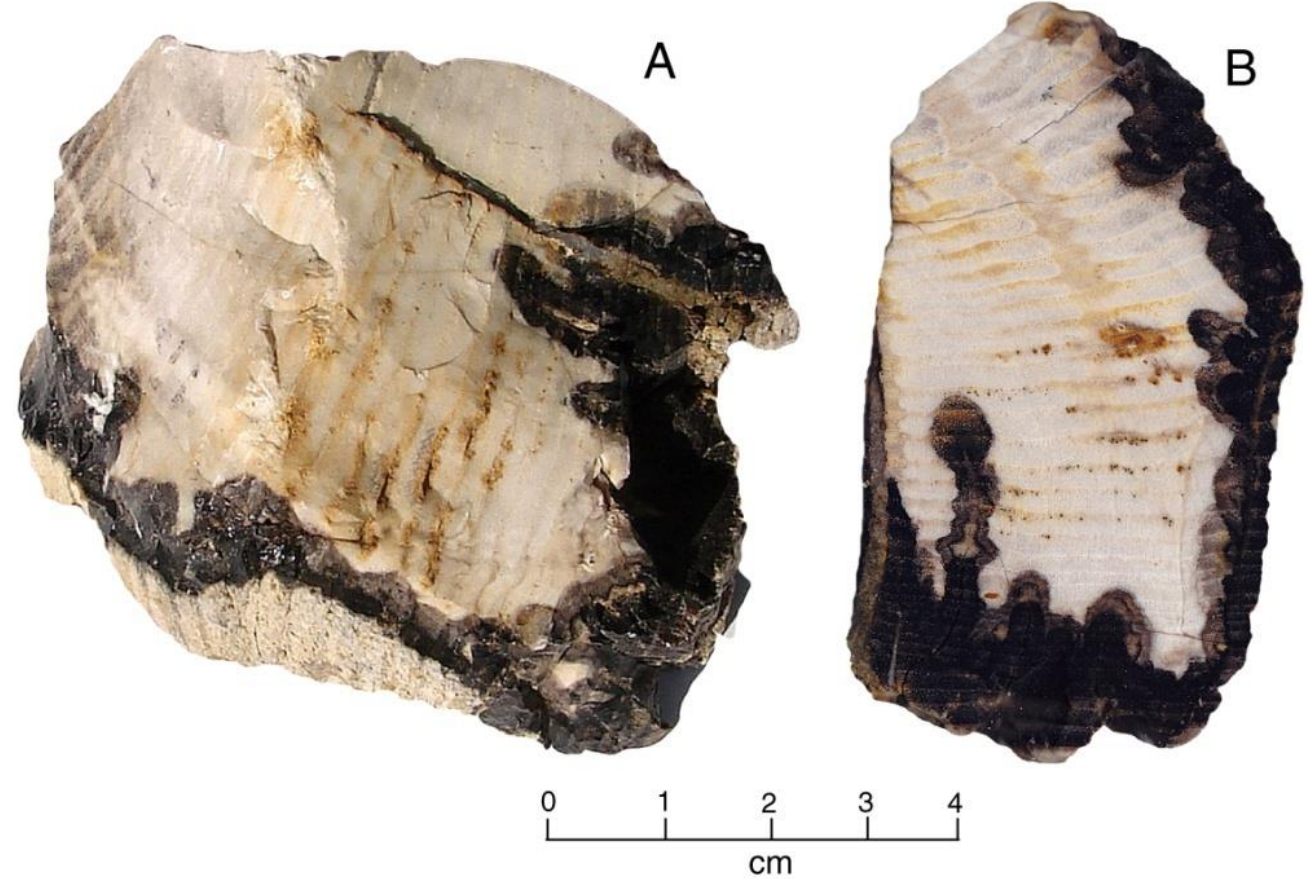

Figure 6. Yakima Ridge Selah Butte specimen SB-7. Opalized Fraxinus wood has carbonized outer margin. (A) Fractured surface, as collected in the field. (B) Sawn cross-section. The shapes of the dark areas suggest that the charring of the exterior surface was accompanied by diffusion of combustion products into the interior region along small fissures.

\section{Methods and Materials}

Specimens used for this study came from research collections of the authors, supplemented by specimens borrowed from the University of Washington Burke Museum of History and Culture, and supplemented by donations by other collectors.Petrographic thin sections were prepared by Mustoe, using the conventional thickness of $30 \mu \mathrm{m}$. Photomicrographs were made using a Zeiss Pol petrographic microscope (ZEISS, Oberkochen, Germany) equipped with an unbranded 5 megapixel CMOS digital camera (Oxford Instruments, Oxfordshire, England). SEM images are from a Tescan Vega III SEM (TESCAN, Brno, Czech Republic), using fractured wood fragments mounted to $1 \mathrm{~cm}$ diameter aluminum stubs using epoxy adhesive. A few specimens were etched for $60 \mathrm{~s}$ in $40 \% \mathrm{HF}$; most were left in their natural state. Specimens were sputter coated with Pd to provide electrical conductivity. X-ray diffraction patterns were obtained from packed powders measured with a Rigaku MiniFlex diffractometer using Ni-filtered Cuk $\alpha$ radiation (Rigaku, Tokyo, Japan). Measurements were made over a range of $5^{\circ}-55^{\circ} 2-\theta$, at a step scan of $0.02^{\circ}$ at a $2^{\circ} / \mathrm{min}$ scan rate. Density measurements were calculated by weighing samples using 
a Mettler analytical balance equipped with a hydrostatic weighing accessory [55]. These laboratory facilities are all housed at Western Washington University.

Jones and Segnit [56] introduced a classification scheme that became the foundation for later opal research. This classification divided opals into four categories: Opal-A, Opal-CT, Opal-C, Opal-AN (hyalite).Opal-A comprises varieties that are highly disordered. Opal-C has an incipient crystallinity of $\alpha$-cristobalite with interlayered tridyite stacking. Opal-C has the structure of well-ordered $\alpha$-cristobalite. Opal-AN includes glassy-textured opals (hyalite) that typically form in igneous rocks as a result of precipitation of silica from a vapor phase. Flörke et al. [57] modified this classification, introducing the name Opal-AG to include precious opal (closely packed silica microspheres) and potch opal (irregular packing of silica microspheres).This classification has primarily been used in some investigations of precious opal (e.g., [58]). We prefer the classification introduced by Jones and Segnit [56] because it is more widely accepted.

Opal-A consists of submicrometer-sized silica spheres with diameters typically in the range of 140-290 $\mathrm{nm}$ [59]; they are typically referred to as nanospheres. Opal-C and opal-CT may occur as spherical aggregates, with diameters in the micron range. These are described as lepispheres. This nomenclature is problematic for opal-A present in silicified wood because this mineral commonly occurs as spherical aggregates with diameters of several microns. In this report, we informally describe these opal-A features as microspheres. The choice of analytical techniques requires consideration of the strengths and weaknesses inherent in each method. SEM images of petrified wood are most likely to reveal anatomical detail when tissues have not been fully mineralized, so that fracture surfaces reveal 3dimensional features. High magnification SEM images may reveal features that are not evident with optical microscopy.

X-ray diffraction patterns may be useful for identifying minerals in fossil wood; however, the method has limitations. Opal-CT results from incipient crystallization of cristobalite interlayered with tridymite, producing recognizable diffraction patterns. Identification of opal-A is less reliable because material produces only a poorly resolved $4 \AA$ A peak that is likely to be obscured in diffraction patterns that contain peaks from other minerals. Another limitation occurs with XRD patterns that reveal quartz peaks; these could come from either cryptocrystalline chalcedony, microcrystalline quartz, or a combination of the two silica polymorphs. Identification of chalcedony is complicated by structural variations. Traditionally, chalcedony has been considered to consist of microcrystalline quartz; however, optical microscopy reveals that chalcedony may contain both length-slow and length-fast fibers. The length-fast fibers have been given the name "moganite", which can be recognized by thermogravimetry, FT-IR spectroscopy, transmission electron microscopy (TEM), and XRD [60-62]. For this investigation, we defined chalcedony as consisting of fibrous $\mathrm{SiO}_{2}$ as evidenced by polarized light optical microscopy and SEM imaging. XRD patterns of these samples lacked the minor peaks characteristic of moganite. It is important to note here that the $\mathrm{X}$-ray diffraction patterns we report were made using conditions chosen to provide analytical consistency for data that were obtained from the 62 specimens listed in Appendix A. Optimized conditions could be used to better-characterize the mineralogy of chalcedony phases (e.g., to possible presence of moganite) or to show the low intensity $\sim 4 \AA$ peak commonly present in opal-A; however, for our research, XRD patterns are a tool for observing comparative compositional variations within a large suite of specimens. For that work it is desirable to employ uniform analytical conditions.

Conventional XRD analyses of geologic materials are usually obtained from powdered samples, so the diffraction patterns show overall average compositions. XRD patterns are therefore of limited value for understanding the details of the fossilization process. For example, similar XRD patterns might result when opalized wood contains quartz-filled fractures, and when angiosperm wood has tracheids and fibers that are mineralized with opal, but conductive vessels that are filled with chalcedony. Examples are described later in this report. 
Measurement of density of silicified wood provides a simple method for evaluating mineral composition [55]. Woods mineralized with opal have densities of $1.9-2.1 \mathrm{~g} / \mathrm{cm}^{3}$, compared to $2.5-2.6 \mathrm{~g} / \mathrm{cm}^{3}$ for woods that are fully mineralized with chalcedony or quartz Densities in the 2.1-2.5 range have several possible explanations. One possibility is that the wood contains porous areas that reduce the density. This porosity may result from cell lumen or conductive vessels that are unmineralized. A second possibility is that the wood contains multiple silica phases, e.g., a mixture of opal and chalcedony. Abundance of relict organic matter may reduce density. Finally, anomalous densities may result from the presence of accessory minerals such as clay, iron oxide, zeolites, or carbonate minerals.

Optical microscope examination of thin sections of fossil wood has long been a mainstay of paleobotany research; however, in most investigations, the slides have been examined under ordinary transmitted light using a biological microscope. These images provide very little information for understanding the fossilization process. In contrast, examination of thin sections using plane polarized light is potentially a very useful method for recognizing the mineralization history.

Scanning electron microscopy can be a valuable tool for observing anatomical characteristics and mineral composition of fossil wood; however, the success of the method depends on the extent of the mineralization. Secondary electron images primarily reveal topography; excellent images can be obtained when intercellular spaces remain open (Figure 7A,B), or when cell lumen are empty (Figure 7C). Woods that are completely mineralized typically yield relatively featureless SEM images (Figure 7D)

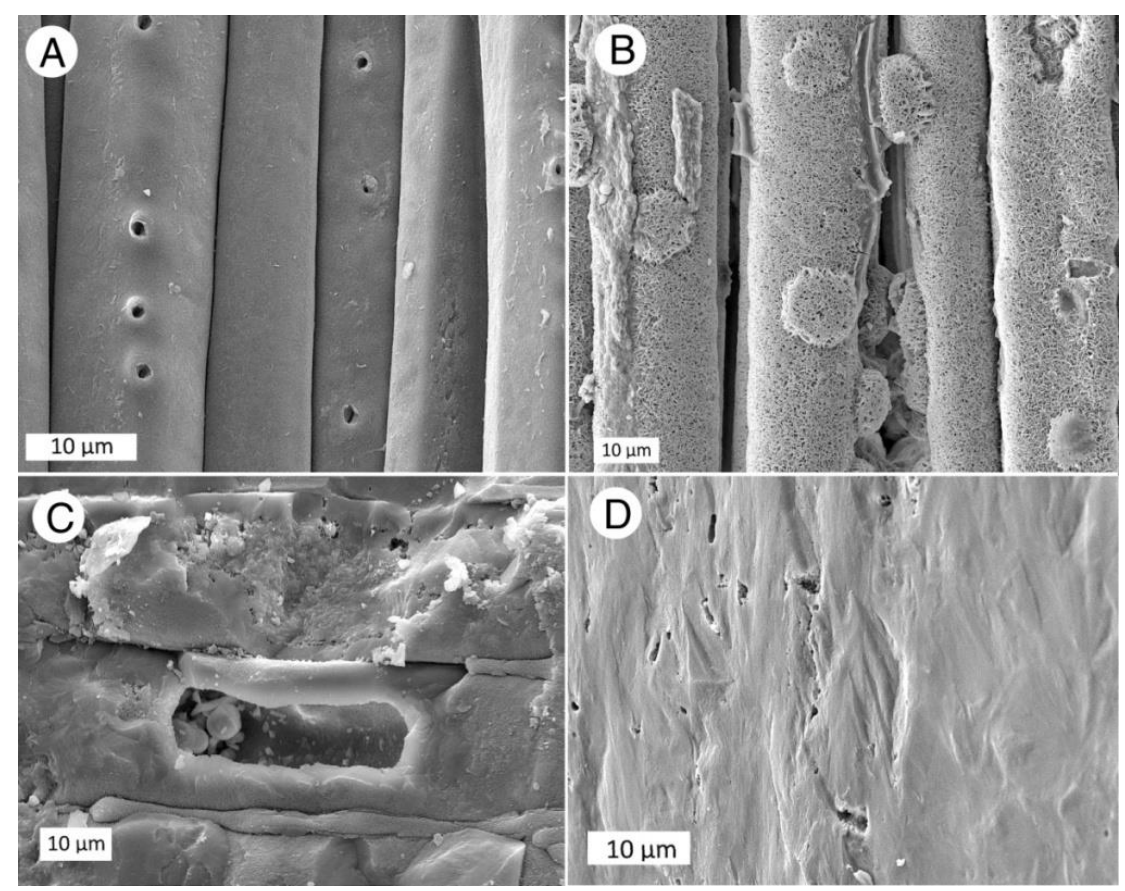

Figure 7. SEM images showing variations in preservation detail. (A) Ginkgo Petrified Forest specimen V5, radial view, opal-A. (B) Ginkgo Petrified Forest specimen V13, radial view, opal-CT.Both specimens show topographic detail because intercellular spaces are not mineralized. (C) UmtanumCanyon specimen U-8, radial view showing hollow ray cells, opal-A. (D) Ginkgo Petrified Forest specimen V10, radial view, extensive opal-A deposition obscures topographic detail.

\section{Results}

The decision to investigate specimens from four fossil wood localities within the CRBG was in part based on the opportunity to determine whether the fossil wood from each locality had distinctive mineral features. The data indicate a complex fossilization process, where mineralogical features vary greatly among specimens within a single deposit, and 
even within an individual specimen. The mineralogical characteristics of samples are shown in Appendix A.

\subsection{Silica Mineralogy}

Four forms of silica have been found in CRBG fossil wood specimens: opal-A, opal-CT, chalcedony, and macrocrystalline quartz. XRD patterns (Figure 8) show that specimens from the various CRBG sites commonly contain mixtures of opal and chalcedony/quartz. XRD patterns do not reveal the presence of opal-A, because this material yields only a very weak diffuse peak. Opal-A can be recognized in polarized light view of petrographic thin sections because of its isotropic nature (Figure 9). Opal-A may also be identified in SEM images because of its physical form (Figure 10).

Opal-CT is a common constituent in CRBG fossil wood. SEM images often show the incipient crystal structure (Figure 11). Well-formed crystals are consistent with the relatively strong XRD peaks measured for these specimens. Low birefringence is a typical opal-CT optical characteristic in polarized light optical photomicrographs (Figure 12).

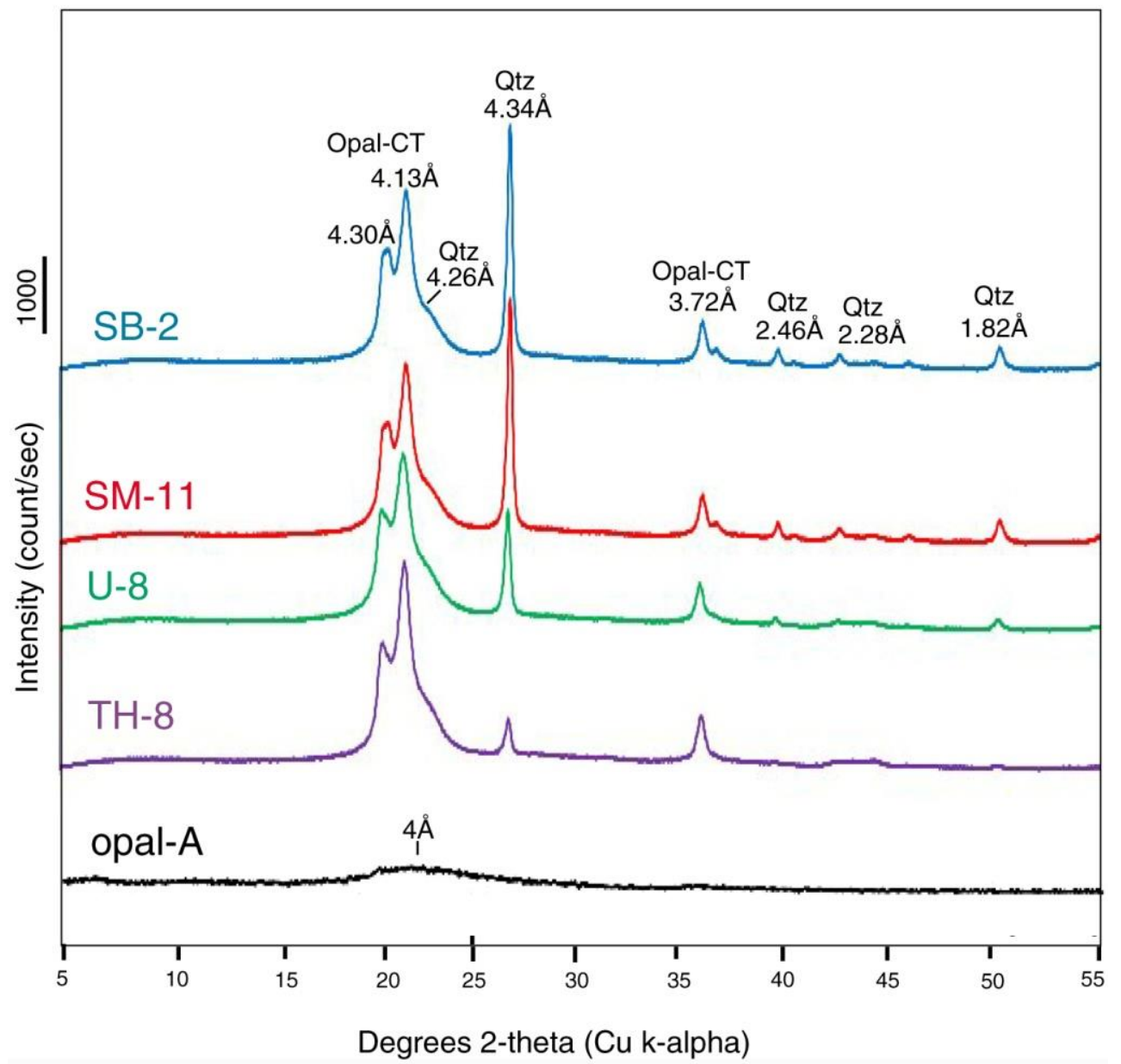

Figure 8. X-ray diffraction patterns reveal that many CRBG wood specimens contain opal-CT as a major constituent, with varying proportions of quartz, the quartz quantity never being very large. The opal-A pattern is from a Nevada, USA Miocene specimen. The lack of a visible small diffuse peak centered at $4 \AA$ for opal-A is a result of the presentation format where all patterns are shown at the same vertical scale. 


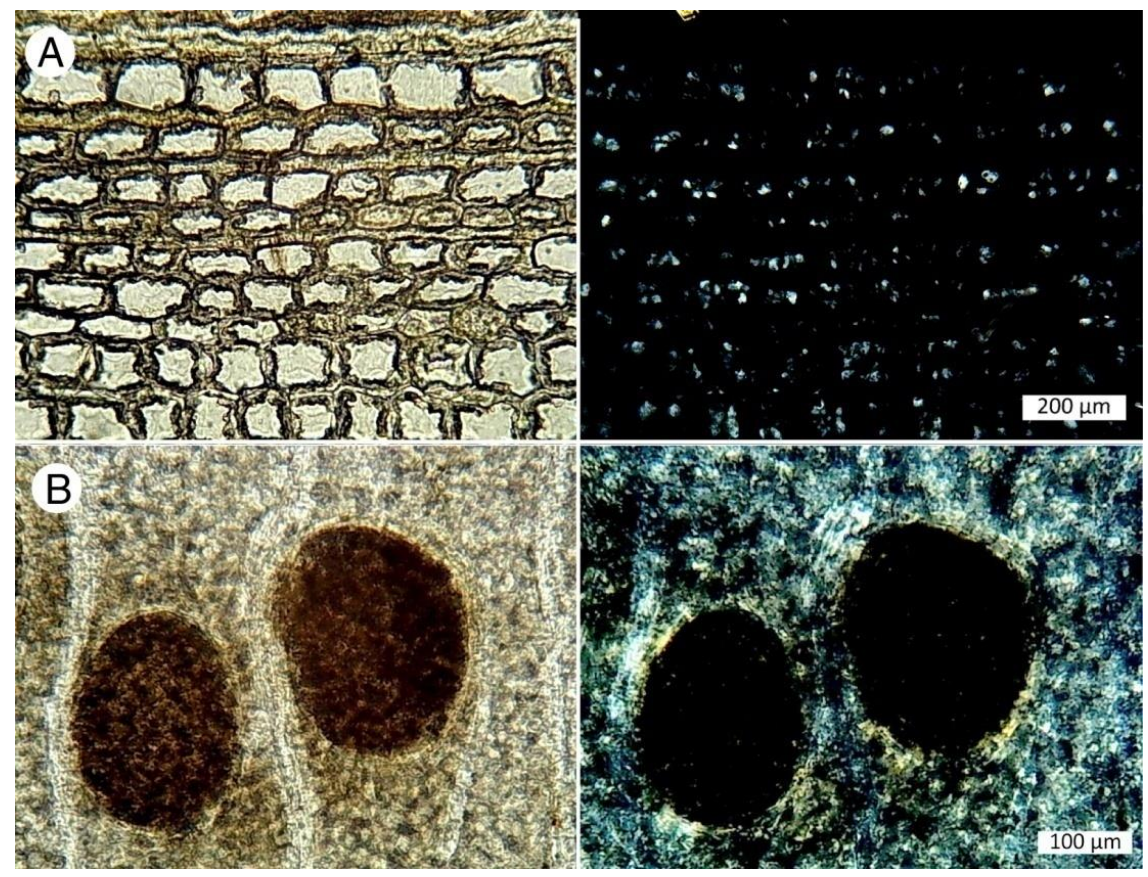

Figure 9. Optical photomicrographs of opalized wood showing transverse views. For each pair, the photo on the left is illuminated with ordinary transmitted light; photo on right shows cross-polarized transmitted light. (A) Opalized wood, Saddle Mountain SM-10. Opacity of polarized light view suggests most of the material is opal-A, with smaller amounts of low birefringence opal-CT present in cell lumen. (B) Yakima Ridge Terrace Heights sample TH-8. Vessels contain opal-A, with surrounding tissue mineralized with opal-CT.

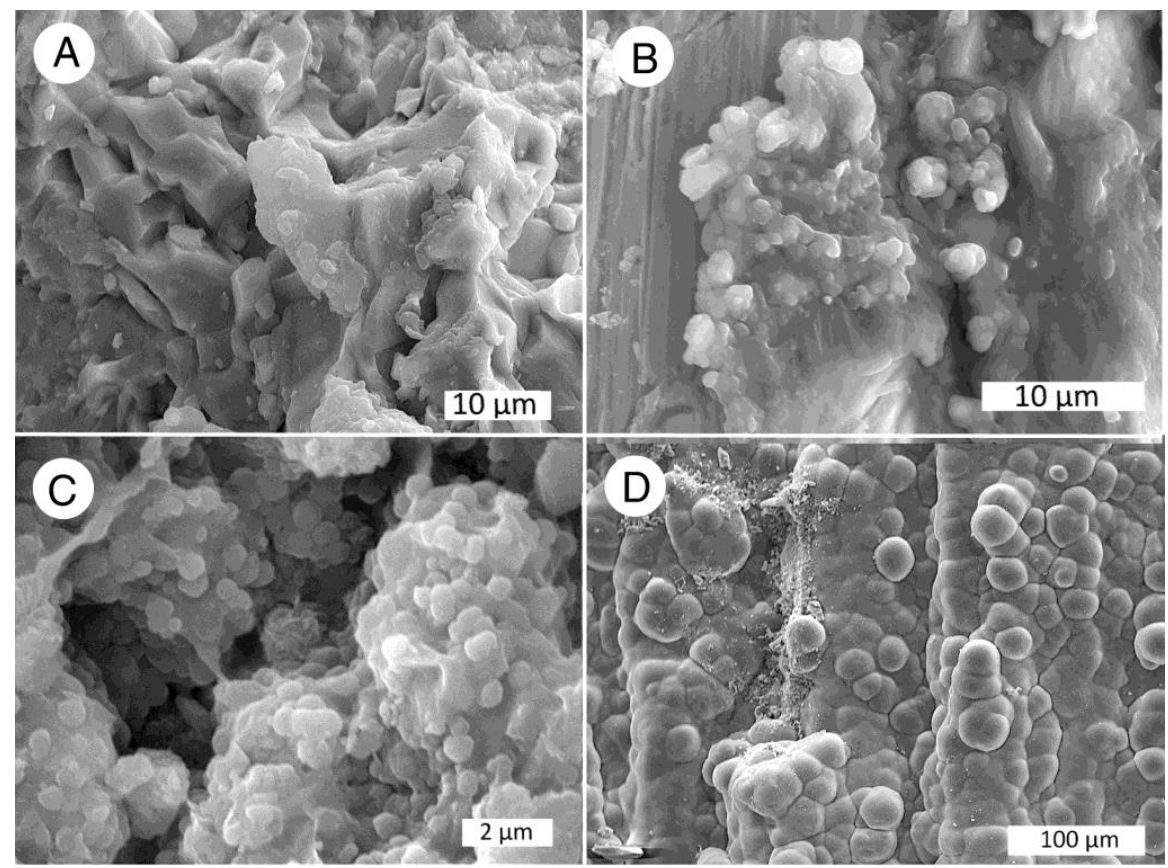

Figure 10. SEM images showing opal-A textures. (A) Yakima Ridge Selah Butte specimen SB-2 view showing cells mineralized with opal-A. (B) Selah Butte specimen SB-2 showing opal-A hemispherical encrustations. (C) Yakima Ridge Terrace Heights specimen TH-1, high magnification view showing opal-A microspheres. (D) Umtanum Canyon specimen U-8, longitudinal view showing three adjacent cells mineralized with botryoidal opal-A. 


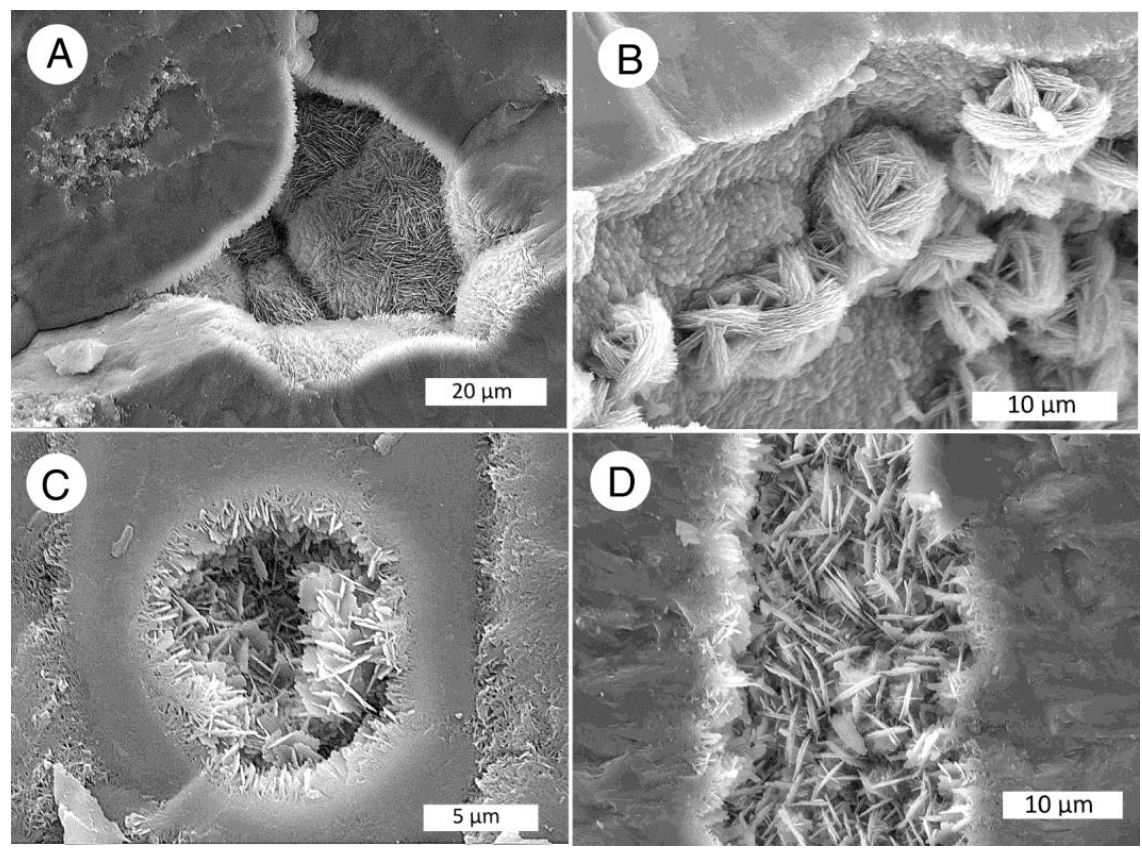

Figure 11. Opal-CT- textures. (A) Yakima Ridge Selah Butte specimen SB-2 (B) Specimen SB-2 showing view showing a vug where opal-CT lepispheres occur on an opal-A substrate. This form of bladed hemispheres has been interpreted as representing an early stages of opal-CT formationwhere intersecting twin planes produce a distinctive architecture [63]. (C) Yakima Ridge Terrace Heights specimen TH-4 radial view showing an intratracheid pit lined with opal-CT. (D) Yakima Canyon specimen YC-2, radial view showing tracheid lumina where open space allowed formation of blade cristobalite/tridymite crystals.

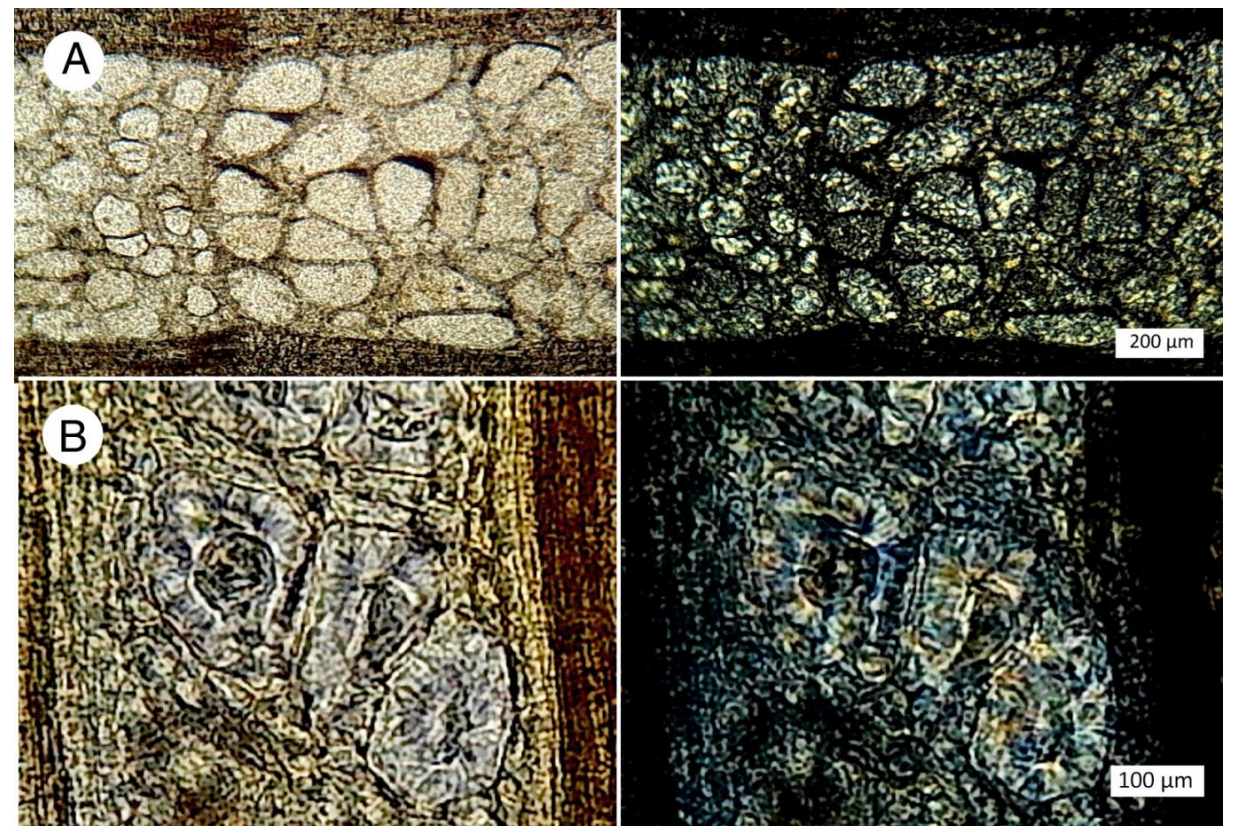

Figure 12. Optical photomicrographs of opalized wood showing transverse views. For each pair, the photo on the left is illuminated with ordinary transmitted light; photo on right shows cross-polarized transmitted light views. Low birefringence of material filling lumen is indicative of opal-CT. Isotropic cell walls may be mineralized with opal-A. (A) Fossil wood from Badger Pocket (an outlier of Ginkgo Petrified Forest). (B) Saddle Mountain specimen SM-1.

Fossil woods that show a major XRD peak at 3.34 Á may contain chalcedony or macrocrystalline quartz. In SEM images, chalcedony may be recognizable because of 
its fibrous structure (Figure 13). Polarized light views of thin sections commonly show chalcedony to have radial architecture (Figure 14).

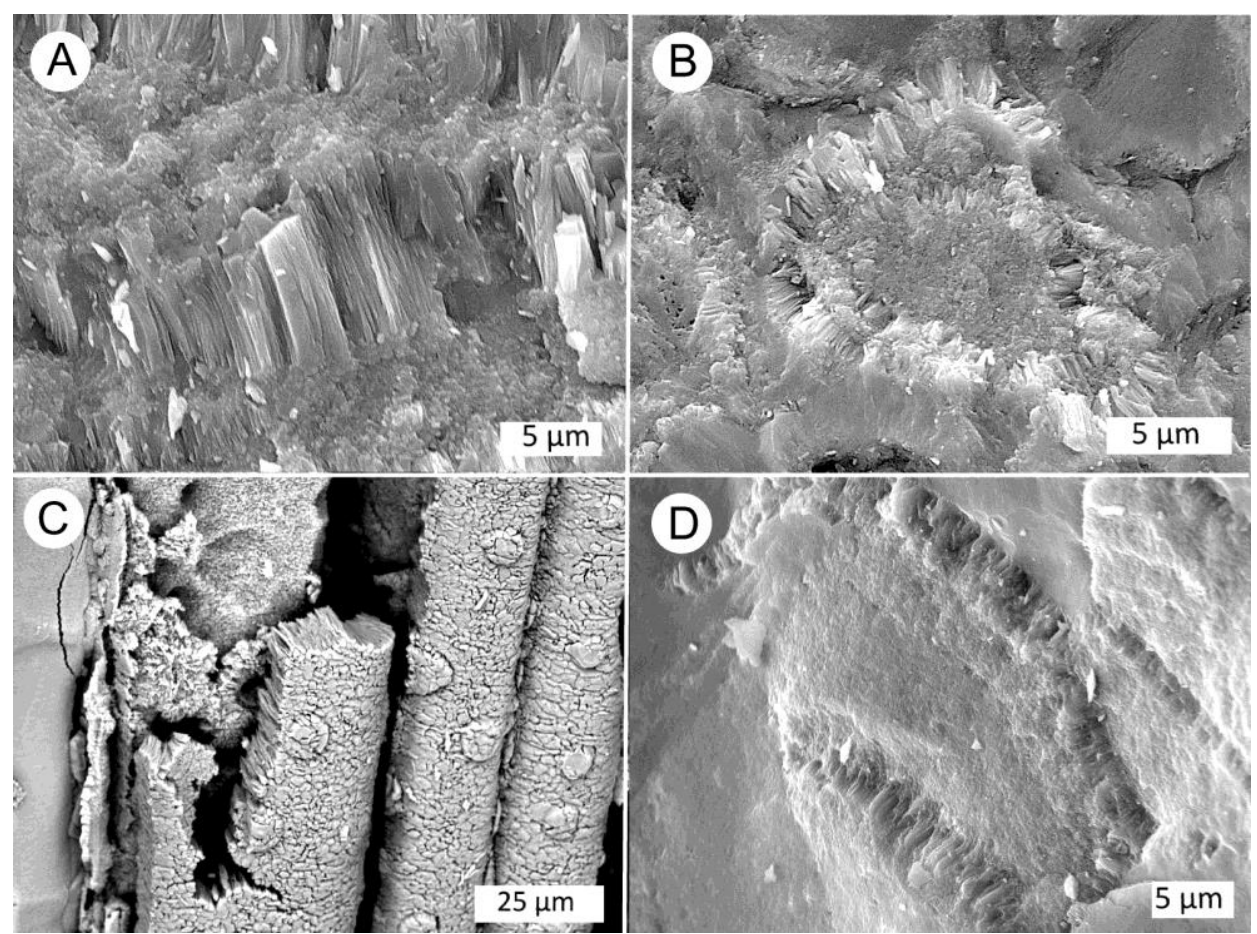

Figure 13. SEM images of wood mineralized with chalcedony. (A) Yakima Ridge Selah Butte sample SB-4. (B) Specimen SB-4 showing a single cell with walls replaced with chalcedony. (C) Yakima Canyon Sample YC-1, after etching $10 \mathrm{~s}$ with 40\% HF. (D) Yakima Ridge Terrace Heights specimen TH-10. Thin seams of chalcedony in opalized wood tissue.

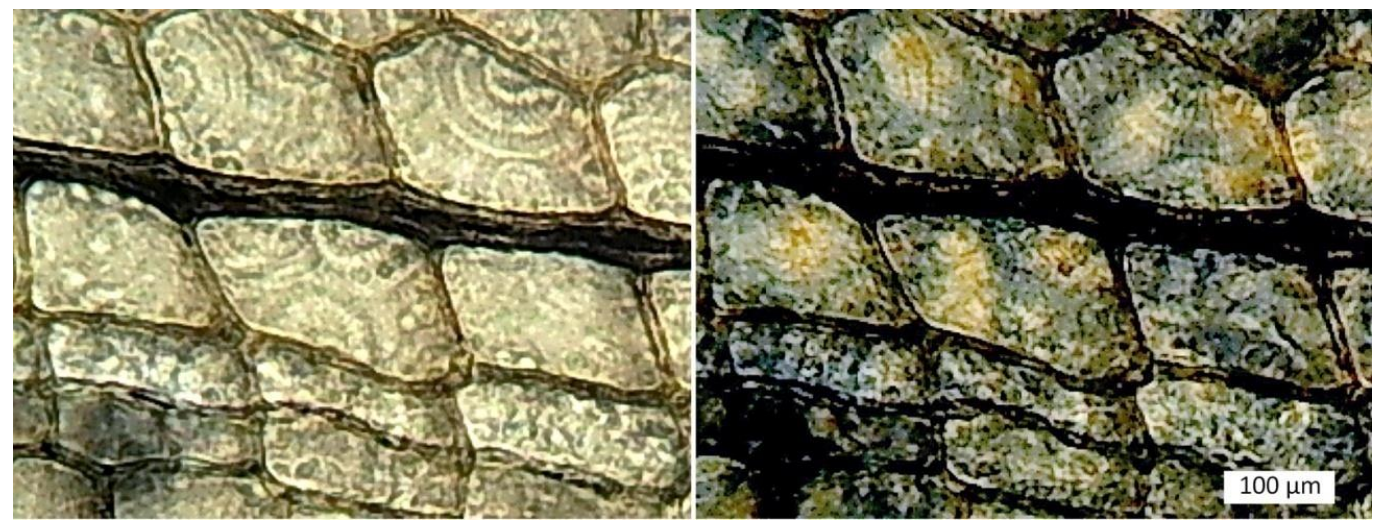

Figure 14. Optical photomicrographs of chalcedony mineralized wood from Saddle Mountain specimen SM-3 wood showing transverse views. The photo on the left is illuminated with ordinary transmitted light; photo on right shows cross-polarized transmitted light.

Macrocrystalline quartz can be recognized in SEM images and thin sections because of its hexagonal crystal habit. Euhedral or subhedral crystals are most likely to be visible when quartz has precipitated in open spaces, allowing terminated crystals to develop (Figure 15).

The above descriptions apply to specimens that have homogeneous mineral composition. However, many CRBG specimens contain an assemblage of silica minerals. The compositional heterogeneities may occur at a variety of scales. Variations in mineral composition can produce distinctive color patterns (Figures 16 and 17). At smaller scale, compositional variations are apparent in petrographic thin sections and in SEM images (Figures 18 and 19). 

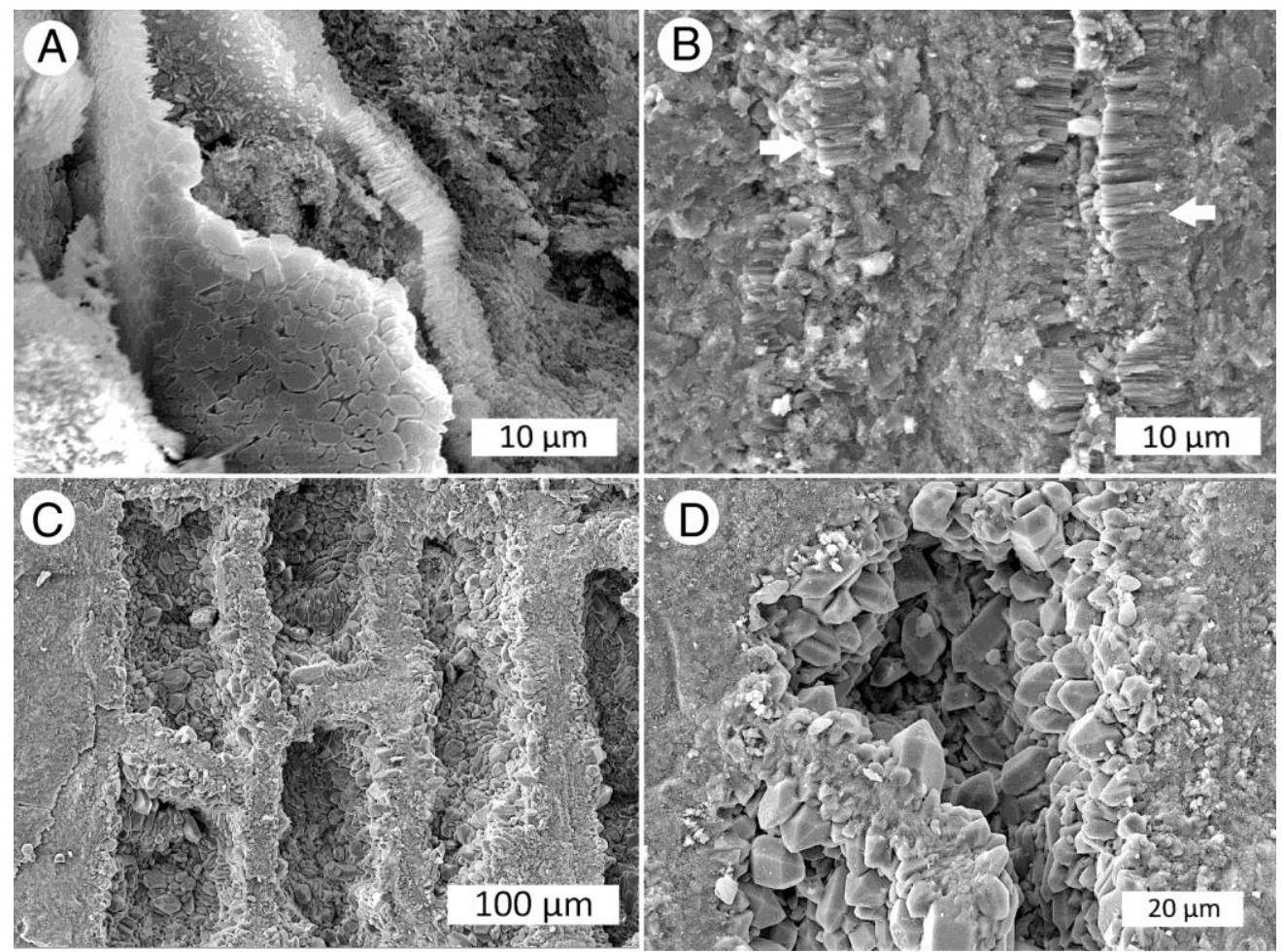

Figure 15. SEM images of wood mineralized with macrocrystalline quartz. (A) Yakima Ridge Terrace Heights specimen TH-5, radial view showing tracheid pits. (B). Terrace Heights specimen TH-6, radial view showing tracheids. (C,D) Ginkgo Petrified Forest fossil oak showing cell walls mineralized with quartz, with empty lumen. The open space allowed quartz crystals to develop sharp terminations.

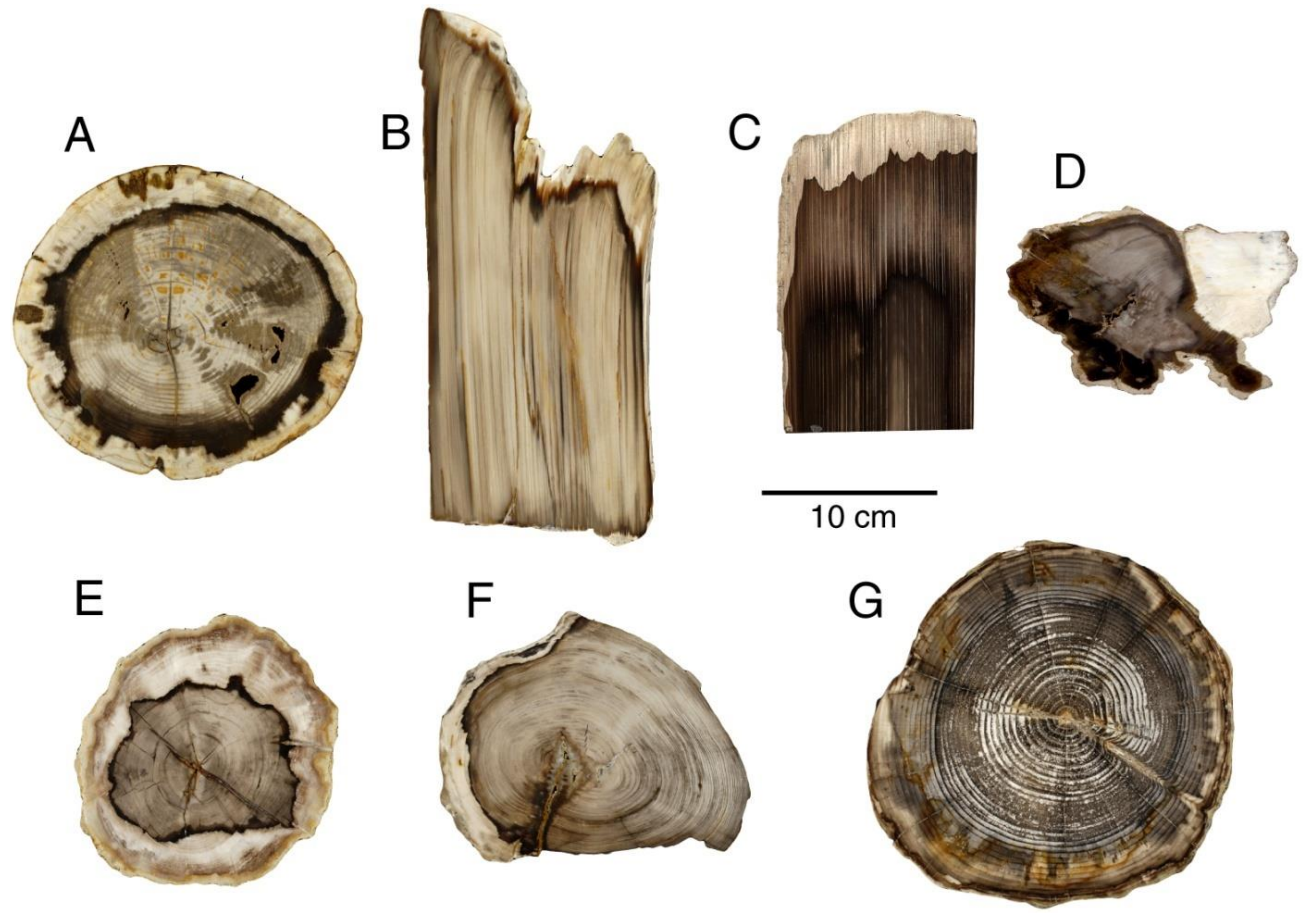

Figure 16. Color patterns in CRBG wood are controlled by compositional variations. (A) Ginkgo Petrified Forest angiosperm, cf. Fraxinus. (B) Saddle Mountain conifer, Cuppressaceae. (C,D) Umtanum Canyon, unidentified conifer. (E) Yakima Ridge Terrace Heights angiosperm, Rhysocaryoxylon. (F) Saddle Mountain conifer, Taxodioxylon. (G) Ginkgo Petrified Forest conifer, Piceoxylon. 

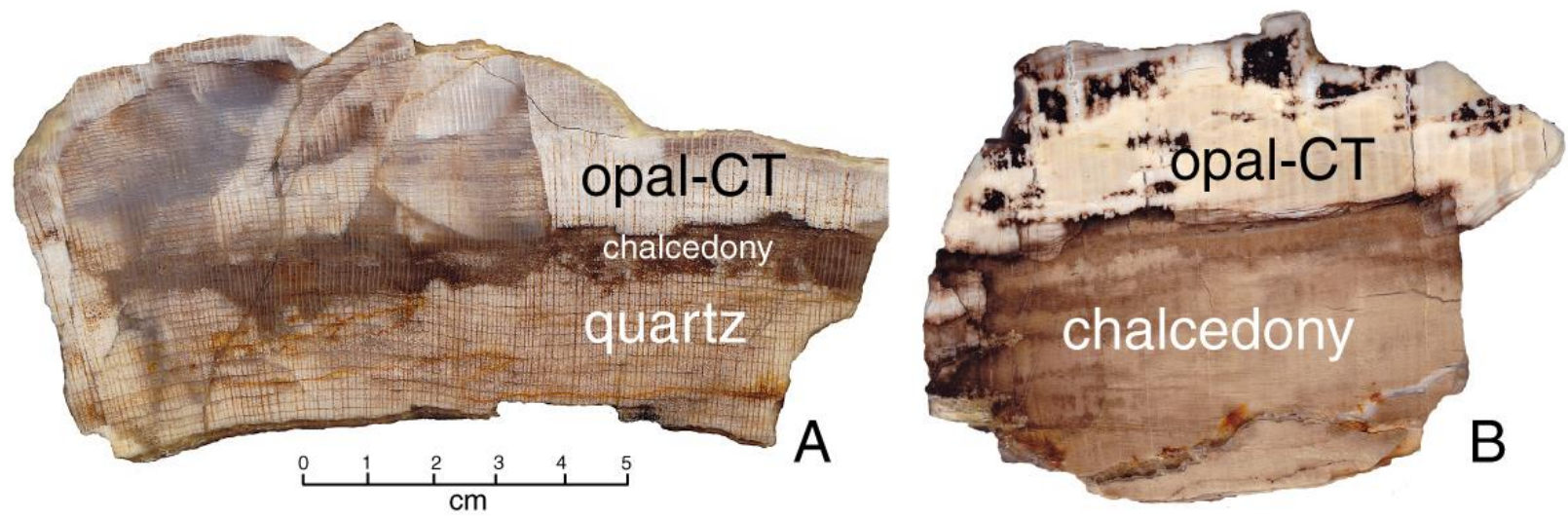

Figure 17. Color patterns related to mixed silica phases. (A) Fossil oak from Ginkgo Petrified Forest, showing color patterns that represent three silica polymorphs. (B) Fossil wood from Yakima Ridge locality at Selah Butte, showing opal-CT and chalcedony mineralized zones.
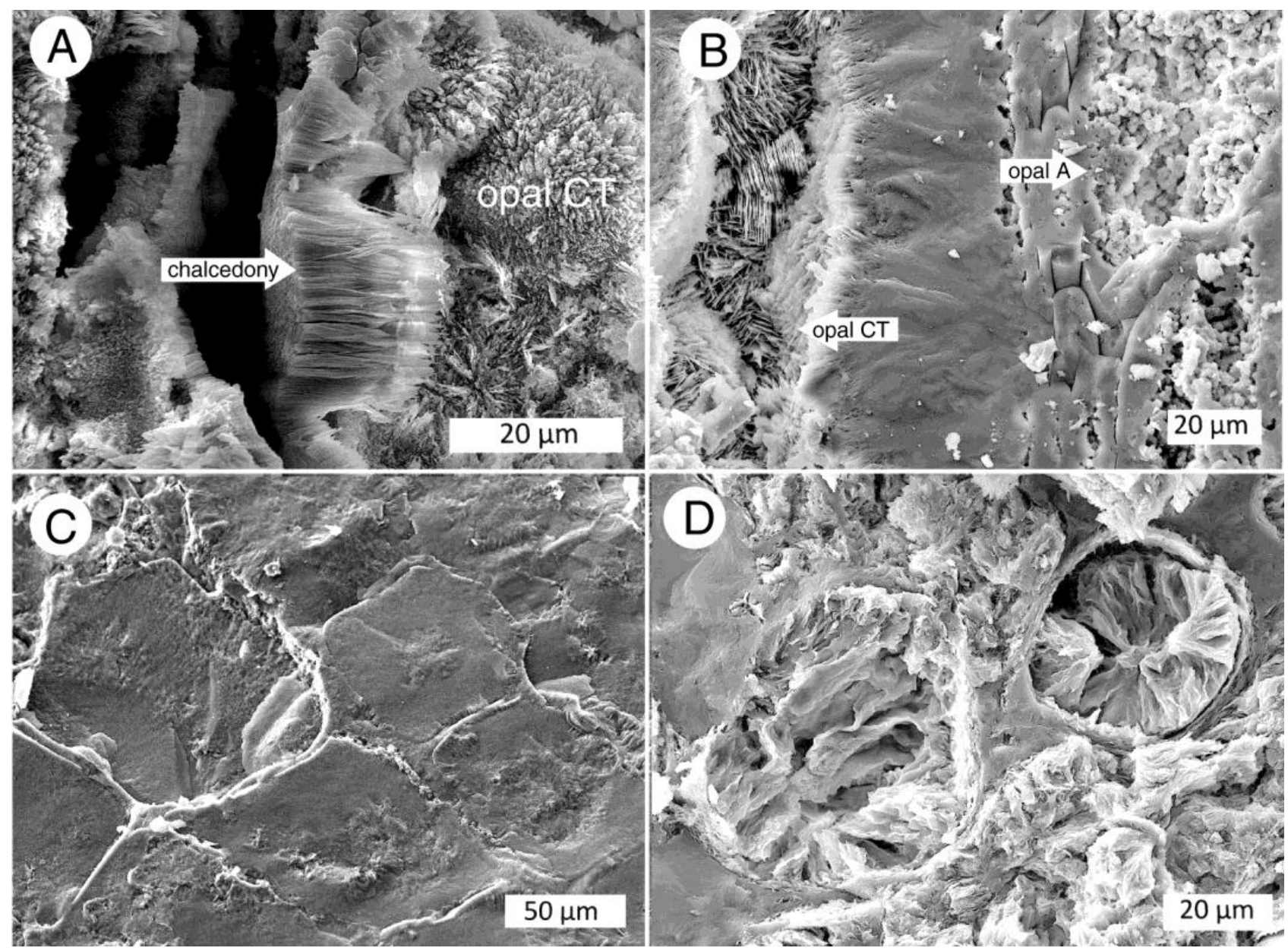

Figure 18. SEM images show that individual specimens may have mineralogic heterogeneity. (A) Saddle Mountain specimen SM-1, etched $60 \mathrm{sec}$. with $40 \%$ HF. Cell wall mineralized with chalcedony, enclosing lumina filled with opal-CT. (B) Terrace Heights specimen TH-3, where two adjacent cell lumen contain different forms of opal, (C) Transverse view of Saddle Mountain specimen SM-1 shows cells solidly filled with opal-CT. (D) Only a few $\mathrm{mm}$ away, the cells contain highly-textured opal, perhaps caused by shrinkage of a hydrous precursor. 


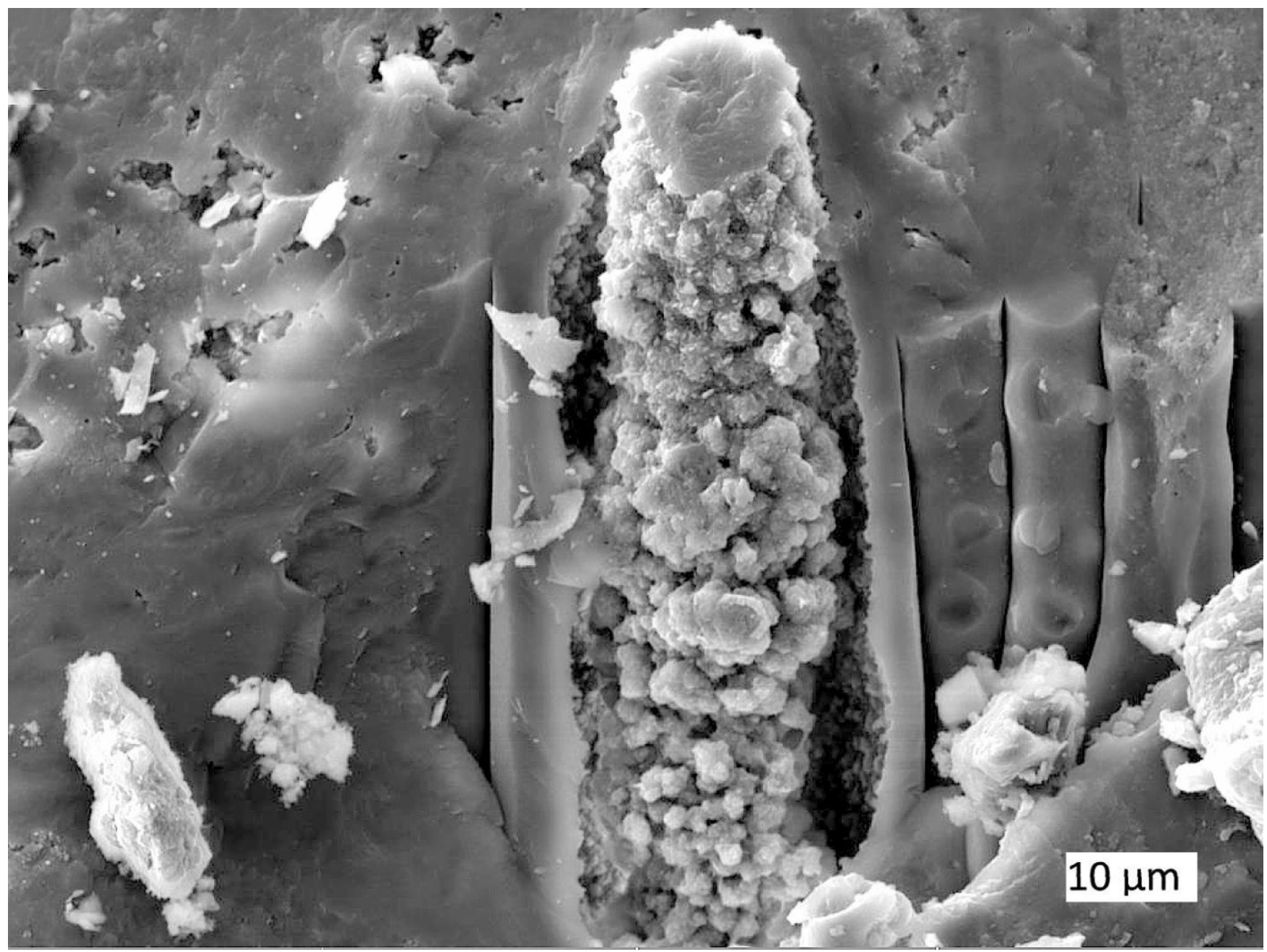

Figure 19. Yakima Ridge Terrace Heights specimen TH-3. Tracheids and fibers are mineralized with opal-CT, but this conductive vessel contains microcrystalline quartz.

Esthetic concerns preclude the destructive chemical analysis of museum display specimens; however, smaller specimens are available for study (Figure 11).

\subsection{Compositional Heterogeneity}

The presence of multiple silica phases in a single specimen has two possible modes of origin. One explanation is that the presence of multiple silica polymorphs is the result of multiple episodes of mineralization, where changes in the geochemical environment caused particular minerals to precipitate from groundwater that permeated the buried wood.

The other possibility is that mineral transformations occurred during diagenesis, where a silica precursor was converted to a different mineral structure. Petrographic evidence shows that many CRBG specimens experienced successive episodes of silica deposition. This phenomenon has been well documented in fossil wood from other locations $[5,12,19]$. For example, many fossil woods contain fractures or rot pockets that have been filled with a type of silica different from the earlier mineralization of cellular tissue. Cross-cutting relationships in silica-filled fractures are evidence of multiple mineralization episodes (Figure 20). 


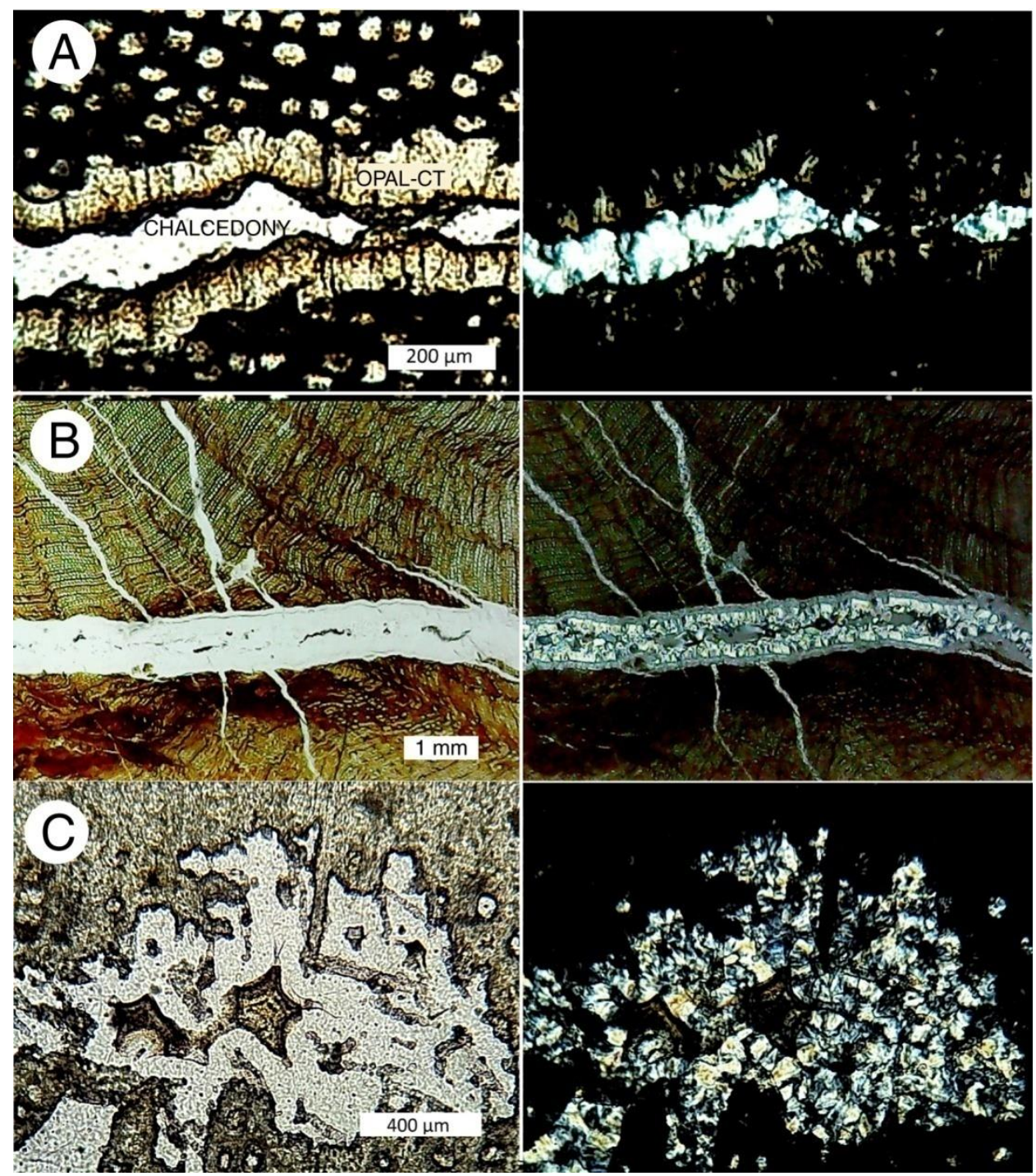

Figure 20. Coexistence of opal and quartz resulting from successive mineralization episodes. For each pair, the photo on the left is illuminated with ordinary transmitted light; photo on right shows cross-polarized transmitted light. (A) Fracture in Yakima Ridge Selah Butte sample SB-4. Cell walls are mineralized with Opal-A, lumen contain opal-CT. A prominent fracture has a lining layer of Opal-CT, with the central region filled chalcedony. (B) Saddle Mountain specimen SM-2. Opalized wood contains networks of fractures that were later filled with crystalline silica. The cross-cutting relationships of these veinlets are evidence that mineralization occurred in several stages. (C) Yakima Canyon specimen YC-7. Quartz fills a complex space in opal-A wood.

Internal layering within fracture fillings clearly shows sequences of silica minerals that were deposited. Figure 21 shows a thin fracture in a Saddle Mountain sample. The wood tissue is mineralized with opal-CT; however, the fracture walls contain thin lining layers of chalcedony that forms a substrate for later deposition of euhedral quartz crystals. The sharp termination of these crystals is evidence that they grew while the central region of the fracture remained open. The quartz crystals are coated by thin layers of opal-A that have both laminar and botryoidal features. The central region contains chalcedony. The overall depositional succession indicated by the wall architecture was chalcedony $\rightarrow$ quartz $\rightarrow$ opal-A $\rightarrow$ chalcedony. 


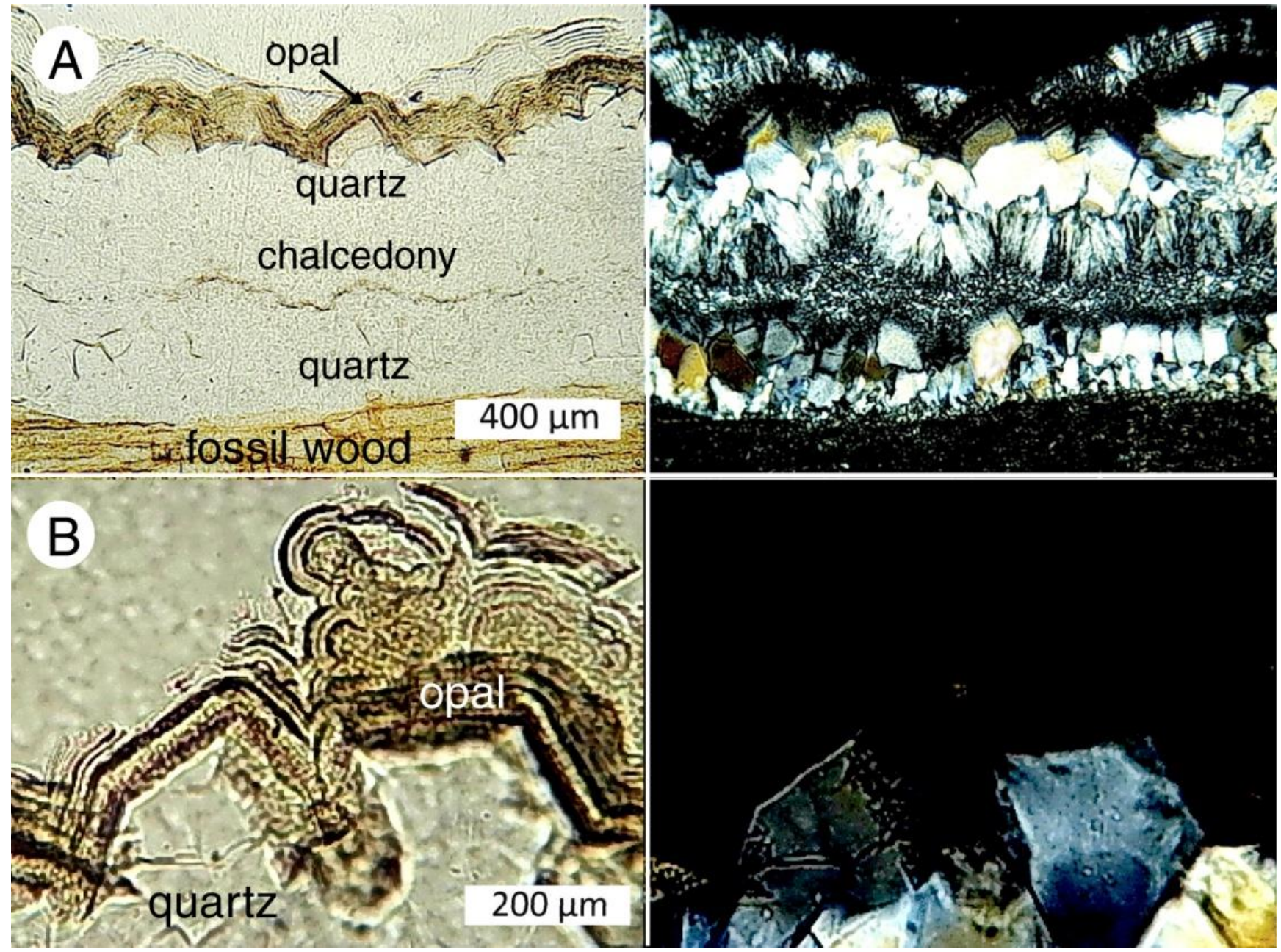

Figure 21. Alternating deposition of opal-A, euhedral quartz, and chalcedony in a thin fracture in opalized wood from Saddle Mountain sample SM-2. For each photo pair, the image on left is ordinary transmitted light, the right image is crossed polarized light. This complex mineralogy exists in a fracture that is less than $2 \mathrm{~mm}$ wide. (A) Laminar opal-A coating a layer of euhedral quartz crystals. The quartz overlies a chalcedony zone, which is positioned above a basal quartz layer. (B) High magnification view shows an area where botryoidal opalA has been deposited on the laminal opal layer.

Another type of multiple-stage mineralization occurred in angiosperm woods where small-diameter cells (e.g., tracheids and fibers) were mineralized with a different form of silica than the material that fills larger-diameter conductive vessels. The most common occurrence is wood tissue that is mineralized with opal, with vessels that contain chalcedony or macrocrystaline quartz (Figure 22). These patterns are evidence that during initial mineralization, the vessels were left as open spaces that provided sites for later precipitation of other forms of silica. This process likely represents the organic templating model, where silica is initially deposited within cell walls because of the ability of silica to form covalent bonds with functional groups present in cellulose and lignin [64,65]. This rapid mineralization produces amorphous silica (opal) at a time when dissolved silica levels are high. Precipitation of chalcedony or quartz in vessels probably represents precipitation from more dilute Si solutions, where slower rates favor the development of well-ordered lattices. 


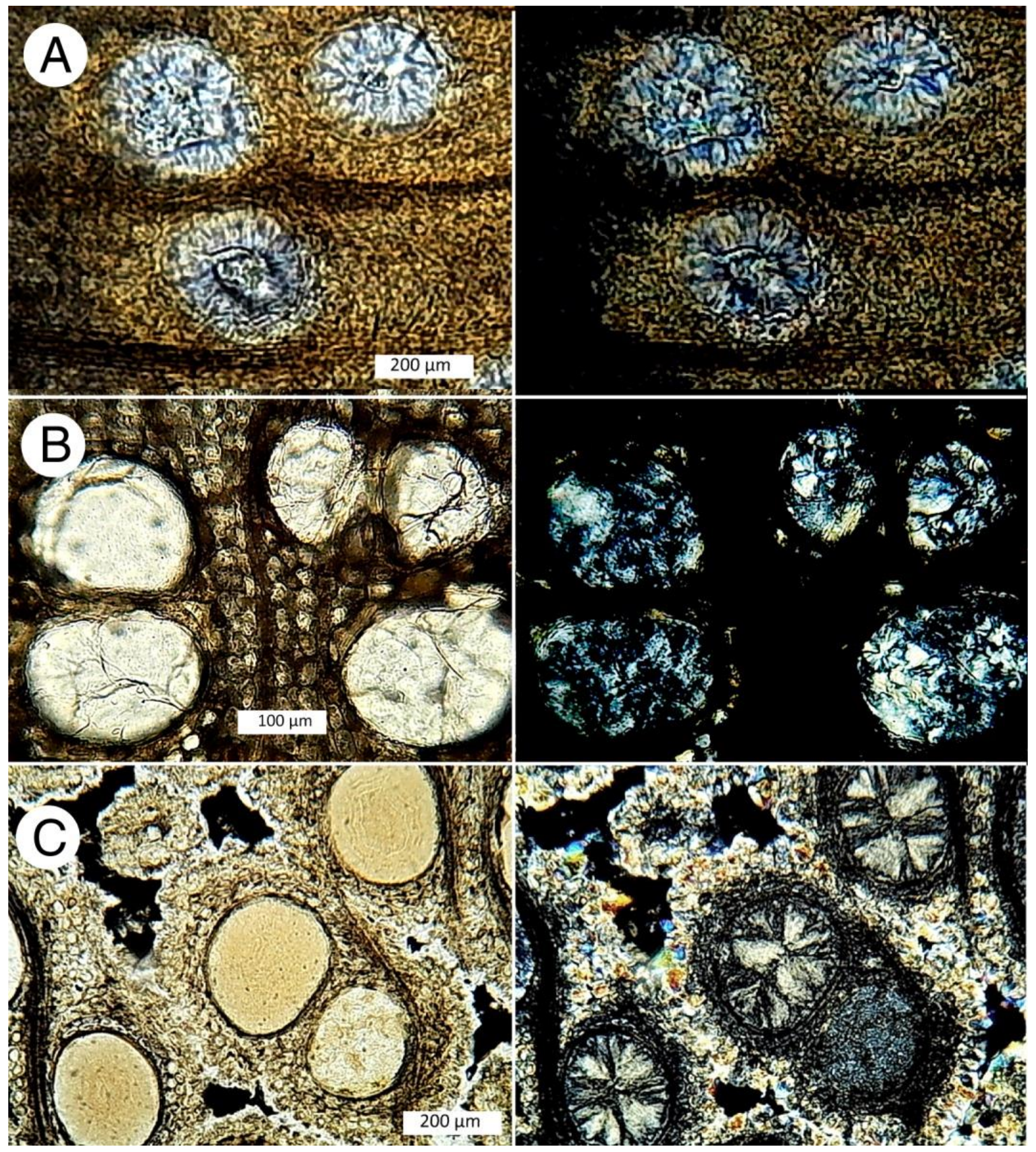

Figure 22. Mineralogy of conductive vessels in silicified angiosperm wood. (A) Yakima Ridge Selah Butte sample SB-1. Opal-CT is the only form of silica. (B) Saddle Mountain sample SM-2, quartz-filled vessels in opalized wood. (C) Yakima Canyon specimen YC-7 Smaller cells are mineralized with microcrystalline quartz, vessels contain chalcedony.

Opaline fossil woods at CRBG localities also commonly contain chalcedony, with macrocrystalline quartz occurring less frequently (Figure 23). Anatomical preservation is consistent with the hypothesis that opalization of the cell walls occurred relatively rapidly, before organic tissue was lost to microbial or chemical degradation. Fidelity of cellular preservation is determined by the rate of initial mineralization versus to the rate of organic degradation [20]. Precipitation of chalcedony and quartz appear to have precipitated later. 


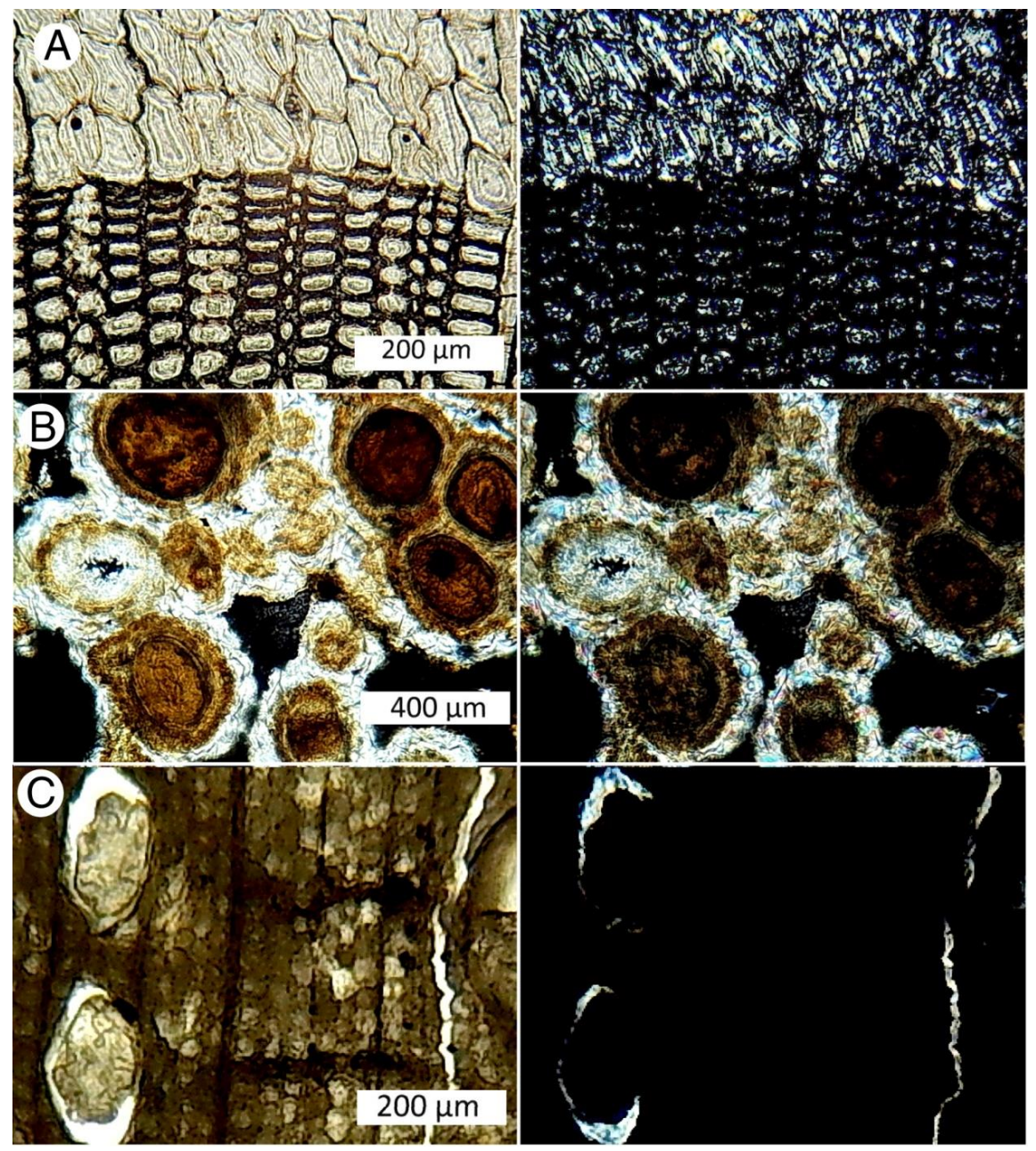

Figure 23. Fossil woods containing opal and chalcedony/quartz. For each pair, the photo on the left is illuminated with ordinary transmitted light; photo on right shows cross-polarized transmitted light. (A)Yakima Canyon specimen YC-3. Transverse view of an annual ring pair. Early wood in upper half of image are large diameter cells that are mineralized with chalcedony. Late wood contains smaller cells with walls that are mineralized with opal, with lumen that are filled with chalcedony. For specimens shown in $(\mathbf{A}, \mathbf{C})$ the absence of opal-CT peaks, and the isotropic nature of the opal in polarized light thin section views suggests that the cell wall opal is amorphous opal-A. (B)Terrace Heights sample TH-2. Conductive vessels mineralized with opal-CT are surrounded by haloes of crystalline quartz. (C) Yakima Canyon sample YC-6, transverse view. Small diameter cells (tracheids and fibers) are mineralized with opal. Vessels contain irregular masses of opal. Shrinkage of this hydrous opal created open spaces that were later filled with chalcedony. A narrow fracture also contains chalcedony.

\subsection{Possible Evidence of Diagenetic Mineral Transformation}

The transformation hypothesis has long been accepted as a valid model for wood petrifaction; however, the supporting evidence is largely circumstantial. In particular, opalized wood is common in Cenozoic deposits, but virtually all Mesozoic and Paleozoic silicified wood is mineralized with chalcedony or quartz. Rare exceptions include the presence opalA in wood preserved Cretaceous deposits in Australia [59], and in Permian silicified wood at Chemnitz, Germany [11] and the Parnaiba Basin, Brazil [14].This temporal pattern supports the hypothesis that opal eventually converts to crystalline forms of silica. Moreover, the solid-state transformation of opal to chalcedony (chert) is well documented for silica sinter in geothermal environments [66] and marine biogenic silica deposits [67,68]. The opal$\mathrm{A} \rightarrow$ opal-CT transition has been studied for opal in sedimentary continental deposits [69]. 
Reports of diagenetic silica transformations in fossil wood have often been based on inference rather than clear evidence. For example, Stein [45] stated "It appears that the recrystallization of silica in petrified wood takes place not only in much the same manner as in marine sediments rich in biogenic opal, but also at much the same rates". These assumptions were based on the assertion that diagenetic temperatures of terrestrial buried wood are similar in magnitude to those of siliceous marine sediments. Geologic evidence was limited to the observation that the degree of crystallinity (crystallization index) increases in proportion to the age of silicified wood specimens, and that opal-mineralized woods were generally Eocene or younger. In contrast, Buurman [1] believed that some chalcedonyand quartz-mineralized Cenozoic woods had formed without the involvement of an opal precursor. Scurfield and Segnit [3] suggested that silica mineralization might depend on the comparative rates of tissue degradation and mineral precipitation, causing some buried woods to be mineralized with chalcedony rather than opal-CT. While acknowledging the possibility of phase transformations, Scurfield and Segnit concluded "Rate of crystal nucleation and growth, determined by the rate of breakdown of cell components, may decide whether opal-CT or chalcedony is formed. The conversion of chalcedonic to quartz specimens is likely, the change of opaline to chalcedonic specimens probable, but the conversion of opal-CT wood doubtful". In the decades following these early reports, experimental studies (e.g., [70-73]) document early silicification processes; however, direct evidence of diagenetic transformations of silica in fossil wood under natural conditions remains sparse and sometimes of questionable validity. For example, descriptions of purported silica phase transformations in fossil woods from Thailand-Myanmar were based on the presumption that specimens that contain more than one silica polymorph resulted from diagentic transformation, without considering the possibility that these mixed phases may have resulted from multiple silicification events under changing geochemical conditions [74].

A phase diagram based on experimental data and field observations (Figure 24) suggests that, under shallow burial conditions, the complete transformation of opal-A to opal-CT is a slow process; conversion of opal-CT to quartz requires even more time. Given their middle Miocene, CRBG fossil wood specimens would be expected to include many specimens that had not yet reached equilibrium, resulting in the coexistence of multiple silica phases. In particular, specimens might show an intermediate stage where amorphous opal-A is developing incipient crystallization. Similar diagenetic trends have been observed in biogenic siliceous sediments collected from extensive deepsea drilling [63].

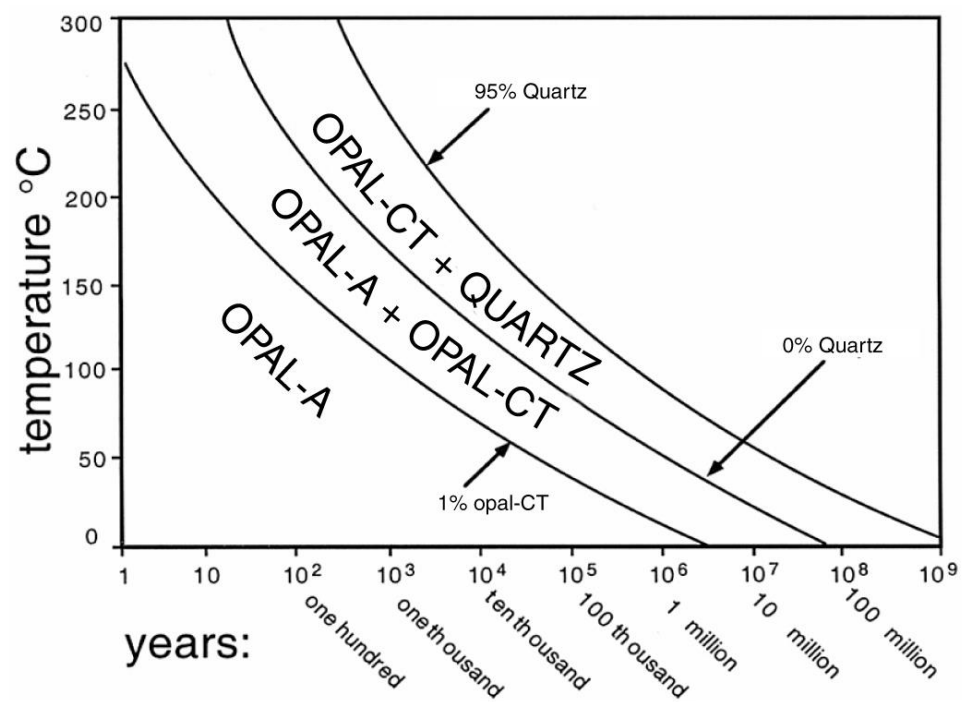

Figure 24. Rates of silica phase transformations as inferred from calculations and observation of natural sediments. Adapted from [75]. 
CRBG fossil woods commonly contain both opal-A and opal-CT as coexisting phases. Indeed, these polymorphs are sometimes present within a single wood cell (Figure 25). Chalcedony and macrocrystalline quartz may also be present. However, textural relationships visible in petrographic thin sections and SEM images suggest that these mixed mineral assemblages were typically not a result of diagenetic transformations.

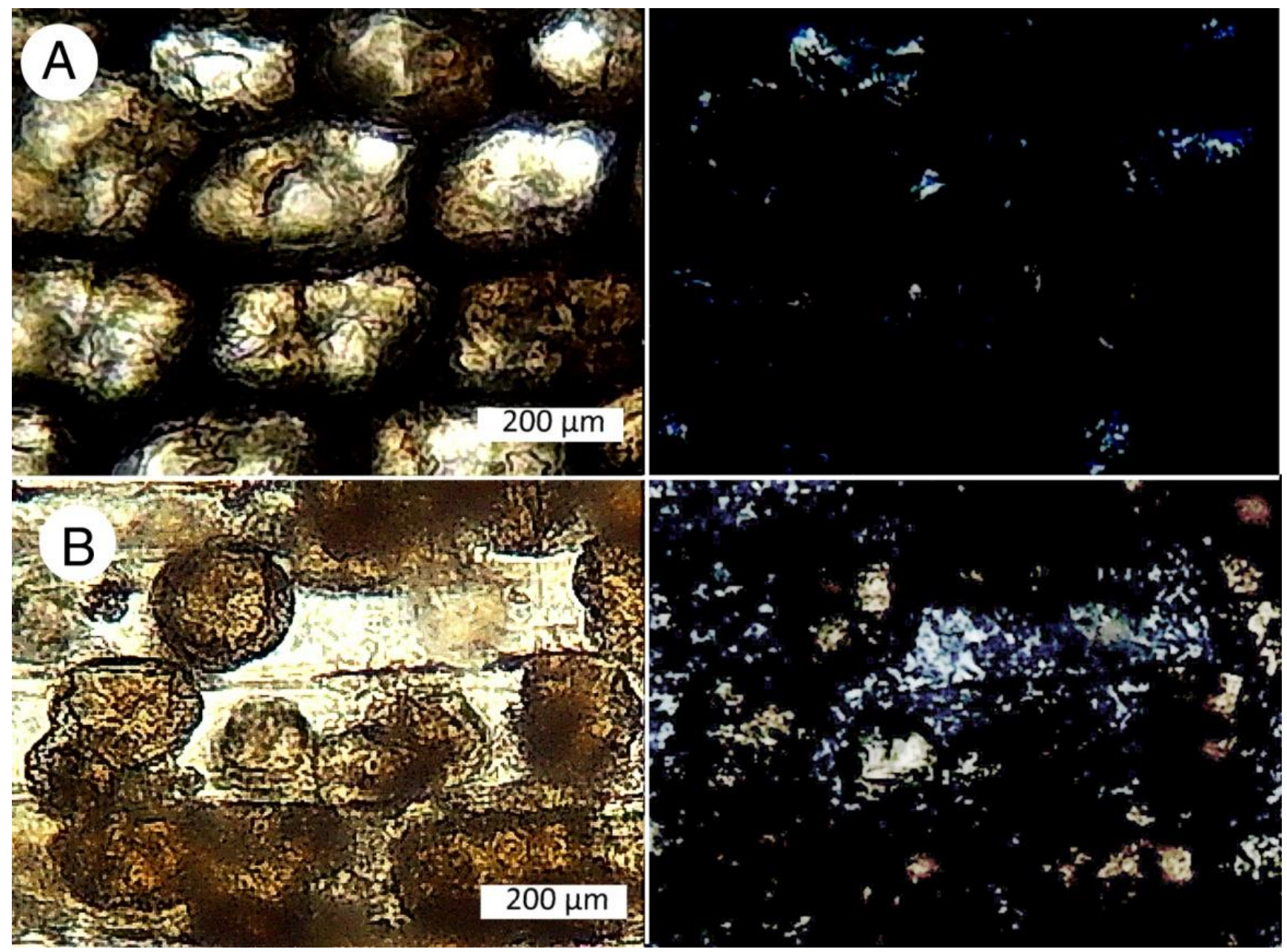

Figure 25. Saddle Mountain sample SM-1 contains cells that contain semi-spherical masses of opal-A surrounded by opal-CT. (A) Opal-A cell walls, with lumen that contain spheroidal masses of opal-A with lesser amounts of opal-CT. (B) Opal-A occurs as spheroids surrounded by opal-CT.

Yakima Ridge Selah Butte specimen SB-8 is an example. As noted previously, logs at this locality were preserved upright within a basalt flow where the wood became opalized. Most Selah Butte specimens preserve this composition. The mineralogy of Selah Butte specimen SB-8 is unusual (Figure 26). Tracheid outer walls are coated with a multitude of small quartz crystals deposited on the surface of cells that are mineralized with $<1 \mu \mathrm{m}$ microspheres characteristic of opal-A. The XRD pattern shows quartz as the only crystalline component; however, the specimen density is only $2.15 \mathrm{~g} / \mathrm{cm}^{3}$. These characteristics suggest that the fossil wood primarily consists in amorphous opal-A. Subsequent precipitation of an overgrowth of quartz crystals was probably a result of a hydrothermal process. 


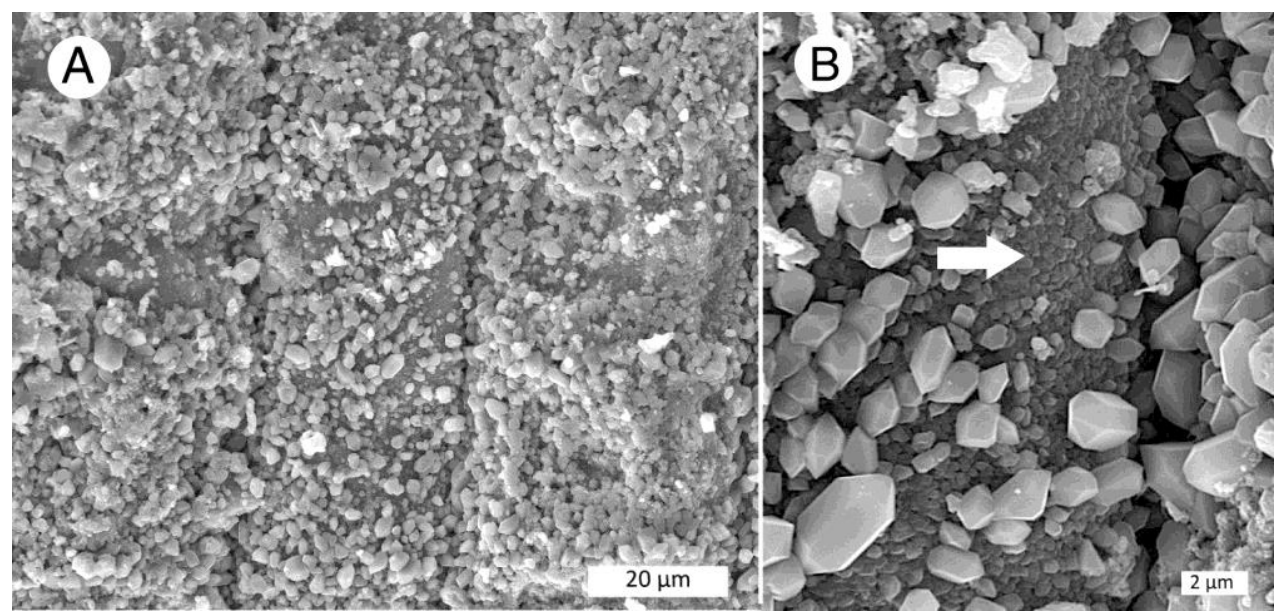

Figure 26. Yakima Ridge Selah Butte specimen SB-8. (A) Hexagonal quartz crystals encrust opal-A mineralized tracheid cells. (B) Higher magnification appears to show opal-A microsphere morphology (arrow).

A few CRBG specimens have characteristics that suggest possible transformations. Examples include Saddle Mountain specimens SM-3 and SM-12 (Figure 27). The XRD patterns show that, for both specimens, quartz is the only crystalline constituent. In SM-12 subhedral quartz crystals occurs adjacent to areas that appear to have textures reminiscent of opal-A microsphere morphology (arrow). Specimen SM-3 also contains relict microsphere shapes (arrows). Both Saddle Mountain specimens have densities of $2.55 \mathrm{~g} / \mathrm{cm}^{3}$ that are diagnostic of pure quartz. These fossil woods may represent transformation of opal-to quartz.
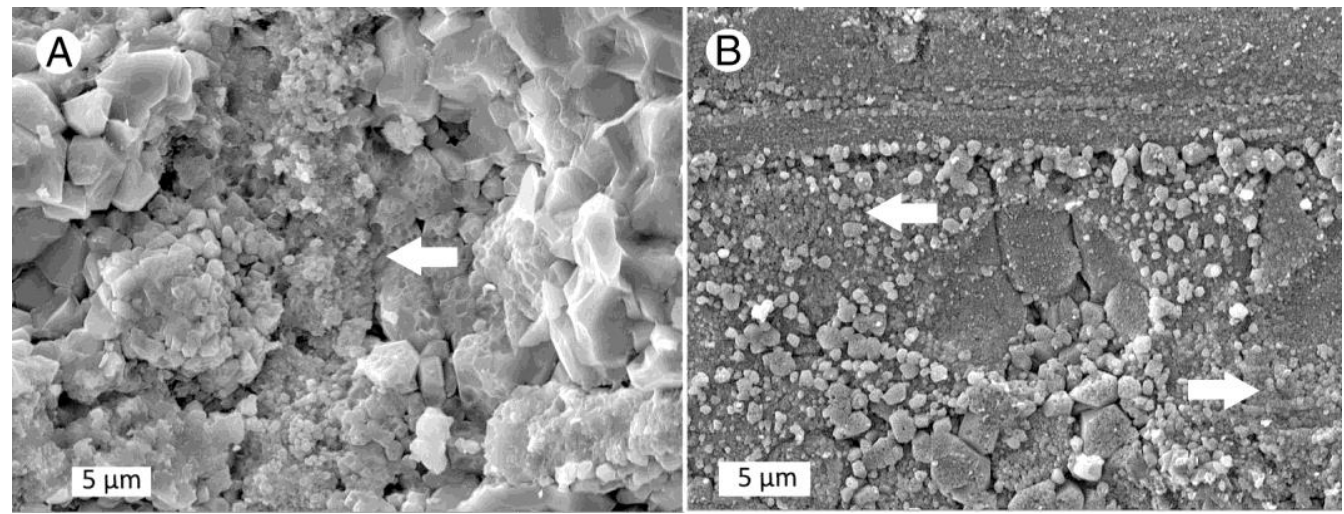

Figure 27. Saddle Mountain specimen SM-12. Quartz-mineralized wood comprising subhedral crystal textures with fine-grained regions where the textures resemble opal-A microspheres. (A) SM-12. (B) SM-3, radial view showing a crossfield pit.

Optical photomicrographs of CRBG fossil wood thin sections reveal specimens where individual cells contain multiple forms of silica. In some specimens, opal-A and opal-CT coexist. In other samples, quartz is also present. The complexity of the mineralization patterns defies easy interpretation. In a previous study of Miocene wood from Nevada, Mustoe [5] suggested that the mineralization of individual wood cells can resemble the lining layers within a geode, where discrete minerals may be precipitated in successive events. Perhaps the silica polymorphs in CRBG wood cells likewise represent a similar style of episodic deposition. In certain instances, the textures suggest the possibility of diagenetic transformation. Figure 28A shows the possible conversion of opal-CT to chalcedony. However, other cells in the same thin section show amorphous zones (opal-A?), surrounded by birefringent silica (Figure 28B). 


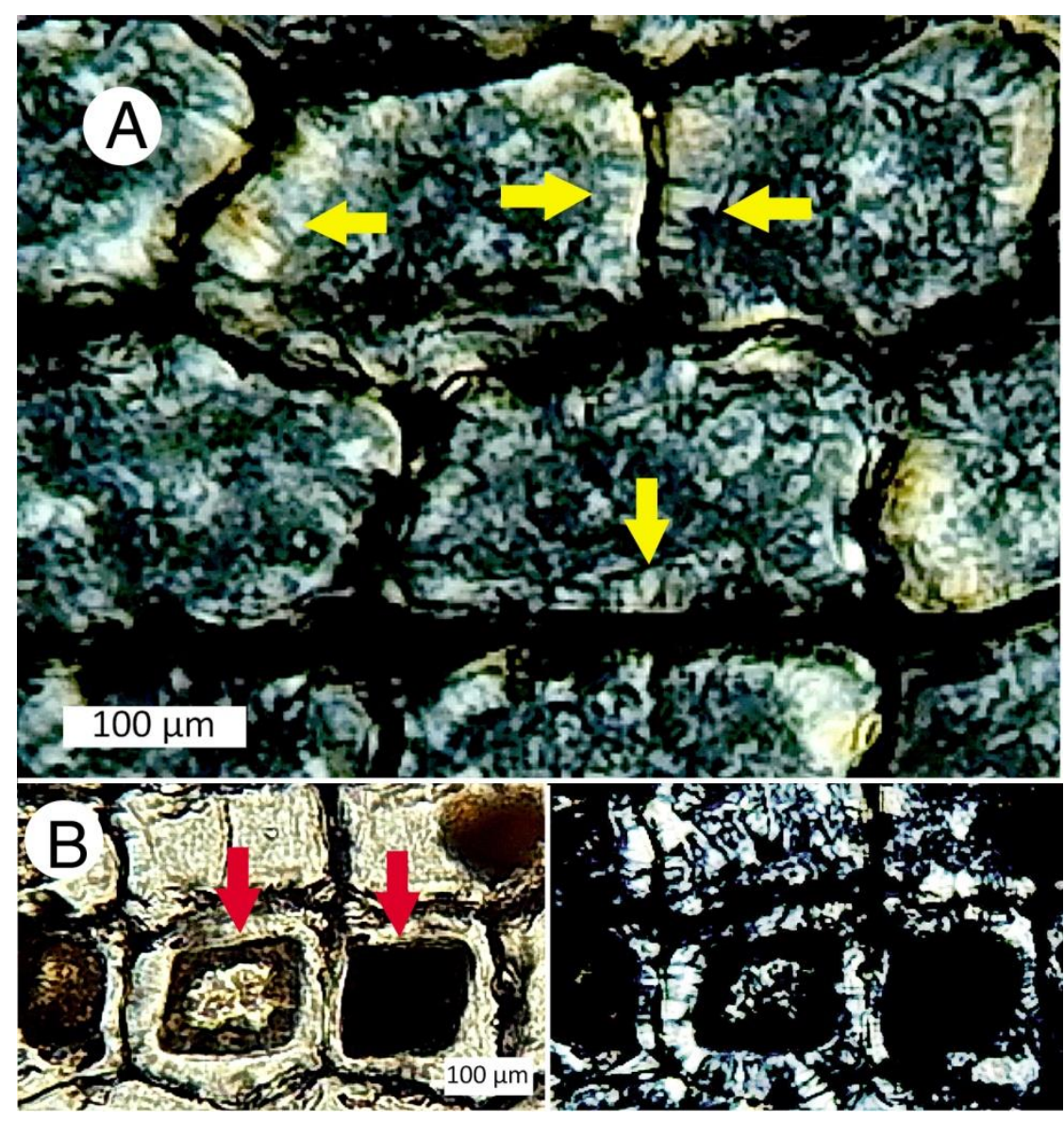

Figure 28. Saddle Mountain sample SM-1. (A)Transverse polarized light view shows that cells contain opal-CT, with marginal regions of slightly higher birefringence and a columnar fabric suggestive of chalcedony (yellow arrows). (B) Nearby cells show inner zones of dark colored mineral isotropic material that is presumed to be opal-A based on the isotropic quality in polarized light views (image at lower right).

\section{Discussion}

None of the four CRBG localities studied for this report have distinctive mineralogy, i.e., an individual specimen cannot be identified as having come from a specific locality based on its mineral composition. However, some general trends can be recognized. Woods from Ginkgo Petrified Forest State Park are highly diverse in mineralogy, ranging from nearly pure opal to pure chalcedony. Many occurrences are tree trunks that contain patterns where opal and chalcedony coexist as separate regions (Figure 10). At Umtanum Canyon, seven of the eight specimens studied are opaline, with opal-A as a major constituent. In contrast, opal wood specimens collected from Saddle Mountain contain only opal-CT, with chalcedony and quartz being common constituents. Opal wood is abundant at Yakima Ridge fossil forest, including both opal-A and opal-CT. Chalcedony and quartz are typically present as late-stage precipitates, with these minerals occurring as fracture fillings or in cell lumen. Precipitation of these crystalline phases occurs when dissolved silica levels are relatively low, allowing well-ordered lattice structures to develop. As a generalization, the mineralization history suggests that silicification began as opal precipitation within cell walls, and that subsequent mineralization was a complex process where silica precipitation was influenced by permeability variations within the buried wood and geochemical changes that affected silica-bearing groundwater. The general similarity of fossil woods at CRBG localities is probably the result of the rather uniform major element composition of the basalt flows [76]; volcanic glass can be an important source of dissolved silica in groundwater [77,78]. 


\subsection{Source of Groundwater}

Water trapped in the pores of sedimentary rocks (connate water) was perhaps a source of mineral-laden solutions responsible for the precipitation of silica in buried woods in CRBG strata associated with sedimentary beds. Because the mid-Miocene volcanism predated the tectonic evolution of the North Cascade Range, the absence of a rainshadow made precipitation levels much higher than they are today [29]. As a result, most groundwater probably originated from meteoric water that permeated along fractures and stratigraphic contacts. This mineral-laden water is responsible for the initial precipitation of silica minerals; water is present in both adsorbed and structural forms in opal-A and opal-CT [79].

\subsection{Why Is the Mineralogy So Complicated?}

The reason why diagenetic silica transformations have been relatively easy to document for siliceous sinter and diatomite is that both materials have homogeneous composition, being composed of microparticles of approximately uniform size. For these materials, time and temperatures related to burial depth can cause silica mineral transformations to show stratigraphic distribution [80-84].

Silicification of buried wood involves more complicated processes. In living trees, wood serves two primary purposes: structural support of the leaf crown and the upward transport of nutrient-bearing liquids. Fluid permeability persists in buried tree trunks, which is not surprising given that, in a living tree, most of the interior tissue is dead. Mineralization occurs when minerals dissolved in groundwater are absorbed by the buried wood. Initial silica deposition typically begins on cell wall surfaces because of "organic templating". Mineralization of intercellular spaces, vessels, fracture spaces and rot pockets may occur during later episodes, when the geochemical environment has changed. For example, high dissolved silica levels favor rapid precipitation of opal. Lower silica levels result in slower precipitation rates, allowing formation of chalcedony and quartz.

This description is a simplification of a petrifaction process that can be very complex. For example, permeability may be different in various regions within a single log. In some woods, Interior "heartwood" regions have cells that have been partially filled with cellulosic tissue (tyloses) that reduce permeability. Permeability can also vary among neighboring cells. This phenomenon explains the damage that plants can experience during times of drought. If an individual tracheid or vessel develops an air gap, that cell loses its ability to conduct fluids. This desiccation can presumably occur in ancient logs that have been exposed to atmospheric conditions prior to burial. Absorption and internal transport of mineral-bearing groundwater may also be related to the presence of fractures or rotted areas.Clogging of cells can occur if wood surfaces are exposed to sediments whose particles are less than the diameter of the lumen.

How do these parameters affect silicification? Mineral precipitation is influenced by the chemical composition of groundwater, which can vary with time. Mineralization is also affected by temperature, $\mathrm{Eh}$, and $\mathrm{pH}$, which are likewise variable factors. As a result, cells that are highly permeable may by mineralized differently from cells that are less permeable. Similarly, cells in the outer zone of a log may be dissimilar in petrifaction of inner regions. Wood that contains fractures or hollow regions may have differing mineralogy from pristine logs.

CRBG woods were particularly susceptible to mineralization differences because of their paleoecologic characteristics. Logs that had been transported within lahar flows (e.g., Ginkgo Petrified Forest) may have suffered physical trauma prior to final burial. For all CRBG localities, inundation of horizontal logs or standing trees in molten lava could affect cell permeability, a striking example being Yakima Ridge Selah Butte trunks that show carbonization of the outer zone.

In summary, the common coexistence of silica polymorphs in CRBG fossil woods and the abundance of specimens were presumed to make these fossil localities an ideal place for searching for non-equilibrium specimens that record the solid-state transformation of opal-A $\rightarrow$ opal-CT $\rightarrow$ chalcedony/quartz that has long been invoked as an explanation 
for wood silicification. Instead, evidence of this transformation remains tentative; most CRBG woods that contain mixed silica assemblages appear to have resulted from successive episodes of mineralization under differing geochemical conditions. This evidence does not disprove the possibility that silica minerals transform during prolonged burial, and the search for mineralogic "missing links" remains a goal for future research

Author Contributions: G.E.M. made petrographic thin sections, obtained optical and scanning electron micrographs. T.A.D. was responsible for field work and contributed specimens and photographs. G.E.M. wrote the first draft of the manuscript. All authors have read and agreed to the published version of the manuscript.

Funding: This research received no external funding.

Data Availability Statement: Not Applicable.

Acknowledgments: Western Washington University Scientific Technical Services staff member Charles Wandler and Michael Kraft provided technical support for the SEM. Kyle Mikkelson, laboratory manager for the Advance Material Science and Engineering Center, provided access to XRD facilities. Ben Paulson arranged access to the Geology Department thin section laboratory. Jim Landon, Richard Rantz, and Lester Holbrook generously provided specimens and site information. Specimens from Vantage and Umtanum Canyon were loaned by the University of Washington Burke Museum of Natural History and Culture.

Conflicts of Interest: The authors declare no conflict of interest.

Appendix A

\begin{tabular}{|c|c|c|c|c|c|c|c|}
\hline \multicolumn{8}{|c|}{ GINKGO PETRIFIED FOREST_-VANTAGE, WA } \\
\hline \multirow{2}{*}{ Sample } & \multirow{2}{*}{$\begin{array}{c}\text { Density } \\
\mathrm{g} / \mathrm{cm}^{3}\end{array}$} & \multicolumn{2}{|c|}{ XRD } & \multicolumn{3}{|c|}{ Thin Section } & \multirow{2}{*}{ Repository } \\
\hline & & Opal-CT & Quartz & Opal-A & Opal-CT & Chalcedony Quartz & \\
\hline V1 & 2.29 & + & + & + & + & & Beck specimen \#353 \\
\hline V2 & 2.25 & + & - & & + & & Beck specimen \#354 \\
\hline V3 & 2.49 & & + & & & + & Beck specimen \#408 \\
\hline $\mathrm{V} 4$ & 2.06 & + & & + & & & Beck specimen $\# 421$ \\
\hline V5 & 2.05 & + & & + & - & & Beck specimen \#423 \\
\hline V6 & 2.49 & & + & & & + & Beck specimen $\# 428$ \\
\hline V7 & 2.50 & + & & & & + & Beck specimen \#431 \\
\hline V8 & 2.40 & + & + & - & + & - & Beck specimen $\# 438$ \\
\hline V9 & 2.22 & + & & & + & + & Beck specimen $\# 470$ \\
\hline V10 & 2.06 & - & & & + & & Beck specimen \#477 \\
\hline V11 & 2.23 & + & & + & + & & Beck specimen $\# 478$ \\
\hline V12 & 2.29 & + & + & + & + & - & Beck specimen \#498 \\
\hline V13 & 1.94 & - & & + & & & Beck specimen $\# 518$ \\
\hline V14 & 2.12 & & - & + & - & & Beck specimen \#569 \\
\hline V15 & 2.35 & & + & & & + & Beck specimen \#582 \\
\hline
\end{tabular}




\begin{tabular}{|c|c|c|c|c|c|c|c|c|}
\hline \multicolumn{9}{|c|}{ UMTANUM LOCALITY \& YAKIMA CANYON OUTLIERS } \\
\hline \multirow{2}{*}{ Sample } & \multirow{2}{*}{$\begin{array}{c}\text { Density } \\
\mathrm{g} / \mathrm{cm}^{3}\end{array}$} & \multicolumn{2}{|c|}{ XRD } & \multicolumn{4}{|c|}{ Thin Section } & \multirow{2}{*}{ Repository } \\
\hline & & Opal-CT & Quartz & Opal-A & Opal-CT & Chalcedony & Quartz & \\
\hline $\mathrm{U} 1$ & 1.99 & + & & + & - & & & Beck specimen $\# 313$ \\
\hline $\mathrm{U} 2$ & 2.05 & + & - & + & + & & & Beck specimen \#321 \\
\hline $\mathrm{U} 3$ & 2.18 & + & + & + & + & & & Beck specimen $\# 322$ \\
\hline $\mathrm{U} 4$ & 2.09 & + & & + & + & & & Beck specimen \#329 \\
\hline U5 & 2.07 & + & - & + & - & & & Beck specimen \#512 \\
\hline U6 & 2.41 & & + & & & + & & Beck specimen \#540 \\
\hline $\mathrm{U} 7$ & 2.03 & + & & + & & & & Beck specimen $\# 574$ \\
\hline U8 & 2.07 & + & - & + & + & - & & WWU specimen \\
\hline YC-1 & 2.53 & & + & & & + & & WWU specimen \\
\hline YC-2 & 2.06 & + & & + & - & & & WWU specimen \\
\hline YC-3 & 2.34 & + & + & + & & + & & WWU specimen \\
\hline YC-4 & 2.36 & + & + & & + & + & & WWU specimen \\
\hline YC-5 & 2.57 & & + & & & + & & WWU specimen \\
\hline YC-6 & 2.17 & + & & & + & - & & WWU specimen \\
\hline YC-7 & 2.04 & & & + & - & & & WWU specimen \\
\hline \multicolumn{9}{|c|}{ SADDLE MOUNTAINS LOCALITY } \\
\hline \multirow{2}{*}{ Sample } & \multirow{2}{*}{$\begin{array}{c}\text { Density } \\
\mathrm{g} / \mathrm{cm}^{3}\end{array}$} & \multicolumn{2}{|c|}{ XRD } & \multicolumn{4}{|c|}{ Thin Sections } & \multirow{2}{*}{ Repository } \\
\hline & & Opal-CT & Quartz & Opal-A & Opal-CT & Chalcedony & Quartz & \\
\hline SM-1 & 2.26 & + & + & & + & + & + & WWU specimen \\
\hline SM-2 & 2.52 & & + & & & + & + & WWU specimen \\
\hline SM-3 & 2.55 & & + & & & + & & WWU specimen \\
\hline SM-4 & 2.17 & + & - & & + & + & - & WWU specimen \\
\hline SM-5 & 2.41 & + & + & & + & + & & WWU specimen \\
\hline SM-6 & 2.45 & & + & & & + & & WWU specimen \\
\hline SM-7 & 2.64 & & + & & & + & & WWU specimen \\
\hline SM-8 & 2.24 & + & - & & + & + & & WWU specimen \\
\hline SM-9 & 2.22 & - & + & & + & - & & WWU specimen \\
\hline SM-10 & 2.32 & + & + & & + & + & & WWU specimen \\
\hline SM-11 & 2.25 & + & + & & + & + & & WWU specimen \\
\hline SM-12 & 2.55 & & + & & & . & + & WWU specimen \\
\hline SM-13 & 2.19 & + & - & & + & - & & WWU specimen \\
\hline SM-14 & 2.58 & & + & & & + & & WWU specimen \\
\hline
\end{tabular}




\begin{tabular}{|c|c|c|c|c|c|c|c|c|}
\hline \multicolumn{9}{|c|}{ YAKIMA RIDGE: TERRACE HEIGHTS LOCALITY } \\
\hline \multirow{2}{*}{ Sample } & \multirow{2}{*}{$\begin{array}{c}\text { Density } \\
\mathrm{g} / \mathrm{cm}^{3}\end{array}$} & \multicolumn{2}{|c|}{ XRD } & \multicolumn{4}{|c|}{ Thin Sections } & \multirow{2}{*}{ Repository } \\
\hline & & Opal-CT & Quartz & Opal-A & Opal-CT & Chalcedony & Quartz & \\
\hline TH-1 & 2.06 & + & + & & + & + & + & WWU specimen \\
\hline TH-2 & 2.55 & & + & & & + & + & WWU specimen \\
\hline $\mathrm{TH}-4$ & 2.49 & + & + & & + & + & & WWU specimen \\
\hline TH-5 & 2.54 & & + & & & + & & WWU specimen \\
\hline TH-6 & 2.53 & & + & & - & + & + & WWU specimen \\
\hline TH-7 & 2.23 & + & + & + & + & + & & WWU specimen \\
\hline TH-8 & 2.15 & + & & & + & & & WWU specimen \\
\hline TH-9 & 2.31 & + & + & & + & + & + & WWU specimen \\
\hline TH-10 & 2.27 & + & - & + & & + & & WWU specimen \\
\hline \multicolumn{9}{|c|}{ YAKIMA RIDGE: SELAH BUTTE LOCALITY } \\
\hline \multirow{2}{*}{ Sample } & \multirow{2}{*}{$\begin{array}{c}\text { Density } \\
\mathrm{g} / \mathrm{cm}^{3}\end{array}$} & \multicolumn{2}{|c|}{ XRD } & \multicolumn{4}{|c|}{ Thin Sections } & \multirow{2}{*}{ Repository } \\
\hline & & Opal-CT & Quartz & Opal-A & Opal-CT & Chalcedony & Quartz & \\
\hline SB-1 & 2.44 & & + & & - & + & & WWU specimen \\
\hline SB-2 & 2.04 & + & + & & - & + & & WWU specimen \\
\hline SB-3 & 2.20 & + & - & + & + & - & & WWU specimen \\
\hline SB-4 & 2.08 & + & - & + & + & - & & WWU specimen \\
\hline SB-5 & 1.98 & + & - & & + & - & & WWU specimen \\
\hline SB-6 & 2.20 & + & + & + & + & + & & WWU specimen \\
\hline SB-7 & 1.99 & + & - & + & + & & & WWU specimen \\
\hline SB-8 & 2.15 & + & - & + & + & - & & WWU specimen \\
\hline SB-9 & 2.51 & & + & & - & + & + & WWU specimen \\
\hline
\end{tabular}

\section{References}

1. Buurman, P. Mineralization of fossil wood. Scr. Geol. 1972, 12, 1-43.

2. Stein, C.L. Silica recrystallization in petrified wood. J. Sediment. Petrol. 1982, 52, 1277-1282.

3. Scurfield, G.; Segnit, E.R. Petrifaction of wood by silicaminerals. Sediment. Geol. 1984, 149, 149-167. [CrossRef]

4. Mustoe, G.E. Mineralogy and geochemistry of late Eocene silicified wood from Florissant Fossil Beds National Monument, Colorado. In Paleontology of the Upper Eocene Florissant Formation, Colorado, Geological Society of America Special Paper435; Meyer, H.W., Smith, D.M., Eds.; Geological Society of America: Boulder, CO, USA, 2008; pp. 127-140.

5. Mustoe, G.E. Late Tertiary wood from Nevada, USA: Evidence of multiple silicification pathways. Geosciences 2015, 5, 286-309. [CrossRef]

6. Mustoe, G.E. Uranium mineralization of fossil wood. Geosciences 2019, 9, 133. [CrossRef]

7. Mustoe, G.E. Mineralogy of non-silicified wood. Geosciences 2018, 8, 85. [CrossRef]

8. Mustoe, G.E.; Abbassi, N.; Hosseini, A.; Mndjzadeh, Y. Neogene tree trunk fossils from the Meshgin Shar area, northwest Iran. Geosciences 2019, 10, 283. [CrossRef]

9. Mustoe, G.E. New discovery of Neogene fossil forests in Guatemala. Geosciences 2020, 10, 49. [CrossRef]

10. Mustoe, G.E.; Viney, M. Mineralogy of Paleocene petrified wood from Cherokee Ranch Fossil Forest, central Colorado, USA. Geosciences 2017, 7, 23. [CrossRef]

11. Dietrich, D.; Lampke, T.; Rößler, R. A microstructure study on silicified wood from the Permian Petrified Forest of Chemnitz. Paläontologsche Z. 2013, 87, 397-407. [CrossRef]

12. Viney, M.; Dietrich, D.; Mustoe, G.; Link, P.; Lampke, T.; Götze, J.; Rößler, R. Multi-stage silicification of Pliocene wood: Re-examination of an 1895 discovery from Idaho, USA. Geosciences 2016, 6, 21. [CrossRef]

13. Trümper, J.; Rößler, R.S. Götze Deciphering silicification pathways of fossil forests: Case studies from the late Paleozoic of central Europe. Minerals 2018, 8, 432. [CrossRef] 
14. Trümper, S.; Götze, J.; Rößler, R. Siliceous petrifactions in the Permian of the Parnaiba Basin, central-north Brazil: Sedimentary environment and fossilization pathways. In BrazilianPaleofloras: From Paleozoic to Holocene; Iannuzzi, R., Rößler, R., Kunzann, L., Eds.; Springer Nature: London, UK, 2020; pp. 1-45.

15. Liesegang, M.; Gee, C.T. Silica entry and accumulation in standing trees in a hot-spring environment: Cellular pathways, rapid pace and fossilization potential. Palaeontology 2020, 63, 651-660. [CrossRef]

16. Menci, V.; Matysová, P.; Sakala, J. Silicifieid wood from the Czech part of the Intra Sudetic Basin (Late Pennsylvanian, Bohemian Massif, Czech Republic: Systematic, silicification and palaeoenvironment. NeuesJahrb. Geol. Paläontologie-Abh. 2009, 252, 269-288.

17. Furuno, T.; Watanabe, T.; Suzuki, N.; Goto, T.; Yokoyama, K. Microstrucure and silica mineralization in the formation of silicified woods. I, Species identification of silicified wood and observations with a scanning electron microscope. MokuzaiGakkaishi 1986, $32,387-400$.

18. Furuno, T.; Watanabe, T.; Suzuki, N.; Goto, T.; Yokoyama, K. Microstructure and silica mineralization in the formation of silicified woods II. Distribution of organic carbon and formation of quartz in the structure of silicified woods. MokuzaiGakkaishi 1986, 32, 575-593.

19. Akahane, H.; Furuno, T.; Miyajima, H.; Yoshikawa, T.; Yamamoto, S. Rapid wood silicification in hot spring water: An explanation of silicification of wood in the Earth's history. Sediment. Geol. 2004, 169, 219-228. [CrossRef]

20. Mustoe, G.E. Wood petrifaction: A new view of permineralization and replacement. Geosciences 2017, 7, 119. [CrossRef]

21. Mustoe, G.E. Washington's fossil forests. Wash. Geol. 2001, 29, 10-21.

22. Camp, V.E. Mid-Miocene propagation of the Yellowstone mantle plume head beneath the Columbia River basalt source region. Geology 1995, 23, 435-438. [CrossRef]

23. Camp, V.E. Origin of Columbia River Basalt: Passive Rise of Shallow Mantle, or Active Upwelling of a Deep-Mantle Plume? Geological Society of America: Boulder, CO, USA, 2013; pp. 181-199.

24. Camp, V.E.; Hanan, B.B. A plume-triggered delamination origin for the Columbia River Basalt Group. Geosphere 2008, 4, 480-495. [CrossRef]

25. Coble, M.A.; Mahood, G.A. Initial impingement of the Yellowstone plume located by widespread silicic volcanism contemporaneous with Columbia River flood basalts. Geology 2012, 40, 655-658. [CrossRef]

26. Reidel, S.P.; Camp, V.E.; Tolan, T.L.; Martin, B.S. The Columbia River flood basalt province: Stratigraphy, areal extent, volume, and physical volcanology. In The Columbia River Basalt Province; Reidel, S.P., Camp, V.E., Ross, M.E., Wolff, J.A., Martin, B.S., Tolan, T., Wells, R.E.W., Eds.; Geological Society of America: Boulder, CO, USA, 2013; pp. 1-44.

27. Reidel, S.P.; Hooper, P.R. Volcanism and Tectonism in the Columbia River Flood Basalt Province; Geological Society of America: Boulder, CO, USA, 1989; p. 386.

28. Reidel, S.P. The Columbia River Basalt Group: A flood basalt province in the Pacific Northwest, USA. Geosci. Can. 2015, 42, 151-168. [CrossRef]

29. Mustoe, G.E.; Leopold, E.B. Paleobotanical evidence for the post-Miocene uplift of the Cascade Range. Can. J. Earth Sci. 2014, 51, 809-824. [CrossRef]

30. Orsen, M.J. Biostratigraphy of Columbia River Basalt Group petrified forests, Paper 226-13, Geological Society of America Seattle Annual Meeting, 2-5 November 2003. Geol. Soc. Am. Abstr. Programs 2003, 35, 55.

31. Brockman, C.F. The Story of the Petrified Forest. Ginkgo State Park, Washington; Washington State Parks and Recreation Commission: Olympia, WA, USA, 1984

32. Russell, I.C. A Geological Reconnaissance of Central Washington; U.S. Geological Survey: Washington, DC, USA, $1893 ;$ p. 108.

33. Beck, G.F. Ancient forest trees of the sagebrush area in central Washington. J. For. 1945, 43, 334-338.

34. Beck, G.F. The quest for the sacred Ginkgo. Wash. Hist. Q. 1935, 26, 3-9.

35. Tate, C. Ginkgo Petrified Forest State Park. The Online Encyclopedia of Washington State History. History Link. Available online: https/ / historylink.orh/File/7396 (accessed on 1 August 2021).

36. Beck, G.F. Fossil wood of the far West, Part 5. Northwest Miner. News 1956, 3, 19-22.

37. Tolan, T.L.; Reidel, S.P.; Fecht, K.R. The unusual occurrence of fossil logs within a middle Miocene flood basalt pillow lava complex-An examination of geologic events and processes that created the "Vantage Forest" of central Washington (abstract). EOS Am. Geophys. Union Trans. 1991, 72, 602.

38. Orsen, M. Ginkgo Petrified Forest; Ginkgo Gem Shop: Vantage, WA, USA, 2007; p. 26.

39. Dillhoff, T.A. Fossil Forests of Eastern Washington. Available online: https://www.evolvingearth.org/research/fossil-woodseastern-washington/ (accessed on 17 October 2021).

40. Beck, G.F. Fossil bearing basalts. Northwest Sci. 1935, 9, 4-7.

41. Beck, G.F. Squaw Creek petrified forest of central Washington. In Fossil Woods of the Far West; Informal Publication of Central Washington State University: Ellensburg, WA, USA, 1942; Volume 2, pp. 1-10.

42. Beck, G.F. Tertiary coniferous woods of western North America. Northwest. Sci. 1945, 19, 67-69.

43. Prakash, U. Miocene fossil woods from the Columbia Basalts of Central Washington, III. Palaeoontographica Suppl. B 1968, 122, 181-200.

44. Scott, R.A.; Barghoorn, E.S.; Prakash, U. Wood of Ginkgo in the Tertiary of western North America. Am. J. Bot. 1961, 49, 1095-1101. [CrossRef] 
45. Prakash, U.; Barghoorn, E.S. Miocene fossil woods from the Columbia basalts of central Washington. J. Arnold Arbor. 1961, 42, 165-203. [CrossRef]

46. Prakash, U.; Barghoorn, E.S. Miocene fossil woods from the Columbia basalts of central Washington II. J. Arnold Arbor. 1961, 42, 347-362. [CrossRef]

47. Wheeler, E.A.; Dillhoff, T.A. The Middle Miocene wood flora of Vantage, Washington, USA. IAWA J. Suppl. 7 2009, 106. Available online: https://iawa-website.org/uploads/soft/download/iawa_j_supplements/IAWA\%20J.\%20Suppl.7.\%20Miocene\% 20Wood\%20Flora\%20Vantage.pdf (accessed on 1 August 2021).

48. Reidel, S.P. The Saddle Mountains-The evolution of an anticline in the Yakima fold belt. Am. J. Sci. 1984, 284, 942-978. [CrossRef]

49. Reidel, S.P. Geologic Map of the Saddle Mountains, South-Central Washington; Washington Division of Geology and Earth Resources Geologic MapGM-38: Olympia, DC, USA, 1998; p. 26.

50. 7.5' Beverly Quadrangle Topo Map; U.S. Geological Survey: Washington, DC, USA, 1965.

51. Dillhoff, T.A. A Miocene Forest Assemblage from the Columbia River Basalts of Washington State, USA, Botanical Society of America Botany 2006 Conference, California State University, Chico, CA, USA, Abstract 444. Available online: http://www.2006 .botanyconference.org/engine/search/index.php?func=detail\&aid=444/ (accessed on 16 October 2021).

52. Mapes, L.V. Rare Surprise for Yakima Man: A Forest of Stone. Seattle Times, 4 May 2007. Available online: https://www. seattletimes.com/seattle-news/rare-surprise-for-yakima-man-a-forest-of-stone/ (accessed on 10 August 2021).

53. Tizon, T.A. A Buried Treasure of Trees. Los Angeles Times, 28 June 2007. Available online: https://www.latimes.com/archives/ la-xpm-2007-jun-28-na-petrifiedtrees28-story.html/ (accessed on 10 August 2021).

54. Dillhoff, T.A. Miocene Forest Assemblage in the Columbia River Basalts. Available online: https://www.evolvingearth.org/ research/miocene-forest-assemblage-columbia-river-basalts/ (accessed on 8 December 2021).

55. Mustoe, G.E. Density and loss on ignition as indicators of the fossilization of silicified wood. IAWA J. 2016, 37, 98-111. [CrossRef]

56. Jones, J.B.; Segnit, E.R. The nature of opal. I. Nomenclature and constituent phases. J. Geol. Soc. Aust. 1971, 18, 57-68. [CrossRef]

57. Flörke, O.W.; Graetsch, H.; Röller, M.B.; Wirth, R. Nomenclature and micro- and non-crystalline silica minerals, based on structure and microstructure. NeuesJahrb. Mineral. Abh. 1991, 163, 19-42.

58. Curtis, N.J.; Gascooke, J.R.; Johnston, M.R.; Pring, A. A review of the classification of opal with reference to recent new localities. Minerals 2019, 9, 299. [CrossRef]

59. Liesegang, N.; Milke, R. Australian sedimentary opal-A and its associated minerals: Implications for natural silica sphere formation. Am. Mineral. 2014, 99, 1488-1499. [CrossRef]

60. Flörke, O.W.; Flörke, U.; Giese, U. Moganite: A new crystalline silica mineral. N. Jb. Mineral. Abh. 1976, 149, 325-326.

61. Heaney, P.J.; Veblen, D.R.; Post, J.E. Structural disparities between chalcedony and macrocrystalline quartz. Am. Miner. 1994, 79, 452-460.

62. Parthasarathy, G.; Kunwar, A.C.; Srinivasan, R. Occurrence of moganite-rich chalcedony in Deccan flood basalts, Killari, Maharashtra, India. Eur. J. Miner. 2001, 13, 127-134. [CrossRef]

63. Hesse, R. Diagenesis \#13. Origin of chert: Diagenesis of biogenic siliceous sediments. Geosci. Can. 1988, 15, 171-192.

64. Leo, R.F.; Barghoorn, E.S. Silicificiation of wood. Harv. Bot. Mus. Leafl. 1973, 25, 1-47.

65. Wang, Y.; Xu, H.; Bryan, C. Formation of Petrified Woods: An Organic Molecule-Templated Silica Mineral Precipitation in Nature, Geological Society of America 2001 Annual Meeting, Boston, MA, USA, 1-10 November 2001, USA, Abstracts with Programs, 2001, 33. Available online: https://gsa.confex.com/gsa/2001AM/webprogram/Paper26122.html (accessed on 17 October 2021).

66. Lynne, B.Y.; Campbell, K.A.; Bryony, J.J.; Browne, P.R.L.; Moore, J. Tracking crystallinity in siliceous hot-spring deposits. Am. J. Sci. 2007, 307, 612-641. [CrossRef]

67. Williams, L.A.; Parks, G.A.; Crerar, D.A. Silica diagenesis, I. Solubility controls. J. Sediment. Petrol. 1985, 55, 301-311.

68. Williams, L.A.; Parks, G.A.; Crerar, D.A. Silica diagenesis, II General Mechanisms. J. Sediment. Petrol. 1985, 55, 312-321.

69. Liesegang, M.; Tomaschek, F. Tracing the continental diagenetic loop of the opal-A to opal-CT transformation with X-ray diffraction. Sediment. Geol. 2020, 398, 105603. [CrossRef]

70. Ballhaus, C.; Gee, C.T.; Bockrath, C.; Greef, K.; Mansfeldt, T.; Rhede, D. The silicification of trees in volcanic ash—An experimental study. Geochim.Cosmochim. Acta 2012, 84, 62-74. [CrossRef]

71. Läbe, S.; Gee, C.T.; Ballhaus, C.; Nagel., T. Experimetal silicification of the tree fern Dicksonia Antarctica at high temperature with silica-enriched $\mathrm{H}_{2} \mathrm{O}$ vapor. Palaios 2012, 27, 835-841. [CrossRef]

72. Gee, C.T.; Liesegang, M. Chapter 6. Experimental silicification of wood in lab and field: Pivitol studies and open questions. In Fossilization: Understanding the Material Nature of Ancient Plants and Animals in the Paleontological Record; Gee, C.T., McCoy, V.E., Sander, P.M., Eds.; Johns Hopkins University: Baltimore, MD, USA, 2021; pp. 139-158.

73. Liesegang, M.; Tomaschek, F.; Götze, J. The structure and chemistry of silica in mineralized wood: Techniques and analysis. In Fossilization: Understanding the Material Nature of Ancient Plants and Animals in the Paleontological Record; Gee, C.T., McCoy, V.E. Sander, P.M., Eds.; Johns Hopkins University: Baltimore, MD, USA, 2021; pp. 159-186.

74. Saminpanya, S.; Sutherland, F.L. Silica phase transformations during diagenesis within petrified woods found in fluvial deposits from Thailand-Myanmar. Sediment. Geol. 2012, 290, 15-26. [CrossRef]

75. Mitzutani, S. Silica minerals in the early stages of diagenesis. Sedimentology 1970, 15, 419-436. [CrossRef]

76. Hooper, P.R.; Reidel, S.P.; Brown, C.J.; Holden, G.S.; Kleck, W.D.; Sundstrom, C.E.; Taylor, T.L. Major Element Analysis of the Columbia River Basin; Washington State University: Cheney, WA, USA, 1984; p. 59. 
77. Murata, K.J. Volcanic ash as a source of silica for the silicification of wood. Am. J. Sci. 1950, 238, 586-596. [CrossRef]

78. Matysová, P.; Rößler, R.; Götze, J.; Leichmann, L.; Forbes, C.; Taylor, E.I.; Sakala, L.; Grygar, T. Alluvial andvolcanic pathways to silicified plant stems (Upper Carboniferous-Triassic) and their taphonomic and palaeoenvironmental meaning. Palaeogeogr. Palaeoclimatol. Palaeoecol. 2010, 292, 127-143. [CrossRef]

79. Segnit, E.R.; Stevens, T.J.; Jones, J.B. The role of water in opal. J. Geol. Soc. Aust. 2007, 12, 211-226. [CrossRef]

80. Murata, K.J.; Nakata, J.K. Cristobalitic stage in the diagenesis of diatomaceous shale. Science 1974, 414, 567-568. [CrossRef]

81. Mitzutani, S. Progressive ordering of cristobalite in early stages of diagenesis. Contrib. Mineral. Petrol. 1977, 61, 129-140. [CrossRef]

82. Kastner, M.; Keene, J.B.; Gieskes, J.M. Diagenesis of siliceous oozes-1. Chemical controls on the rate of opal-A to opal-CT transitions-An experimental study. Geochim. Cosmochim. Acta 1977, 41, 1041-1059. [CrossRef]

83. Hein, J.R.; Yeh, H.W.; Barron, J.A. Eocene diatom chert from Adak Island, Alaska. J. Sediment. Petrol. 1990, 60, $250-257$.

84. Mustoe, G.E. Diatomaceous origin of siliceous shale in Eocene lakebeds of central British Columbia. Can. J. Earth Sci. 2005, 42, 231-241. [CrossRef] 